OPEN ACCESS

Edited by:
Wenpei Xiang,
Huazhong University of Science and
Technology, China
Reviewed by:
Rashmi Kaul,
Oklahoma State University,
United States
Hao Qin,

Peking University Third Hospital, China

David H. Abbott,

University of Wisconsin-Madison,

United States

Jing Li,

First affiliated hospital of China Medical

University, China

*Correspondence:

Xiang-Wei Fu

fuxiangwei@cau.edu.cn

Shou-Long Deng

dengshoulong@cnilas.org

Jun $\mathrm{Li}$

lijun8203@163.com

tORCID:

Xiang-Wei Fu

orcid.org/0000-0003-1638-6852

Shou-Long Deng

orcid.org/0000-0003-1187-3037

${ }^{*}$ These authors have contributed equally to this work

Specialty section:

This article was submitted to

Reproduction,

a section of the journal

Frontiers in Endocrinology

Received: 01 December 2021

Accepted: 03 February 2022

Published: 01 March 2022

Citation:

Xu X-L, Huang Z-Y, Yu K, Li J,

Fu X-W and Deng S-L (2022)

Estrogen Biosynthesis and Signal

Transduction in Ovarian Disease.

Front. Endocrinol. 13:827032.

doi: 10.3389/fendo.2022.827032

\section{Estrogen Biosynthesis and Signal Transduction in Ovarian Disease}

\author{
Xue-Ling $\mathrm{Xu}^{1 \neq}$, Zheng-Yuan Huang ${ }^{2 \neq}, \mathrm{Kun} \mathrm{Yu}^{1 \neq}$, Jun $\mathrm{Li}^{3^{*}}$, Xiang-Wei Fu${ }^{1 *}$ \\ and Shou-Long Deng ${ }^{4+}$ \\ ${ }^{1}$ National Engineering Laboratory for Animal Breeding, Key Laboratory of Animal Genetics, Breeding and Reproduction, \\ Beijing Key Laboratory for Animal Genetic Improvement, College of Animal Science and Technology, China Agricultural \\ University, Beijing, China, ${ }^{2}$ Department of Metabolism, Digestion and Reproduction, Chelsea and Westminster Hospital, \\ Imperial College London, London, United Kingdom, ${ }^{3}$ Department of Reproductive Medicine, The First Hospital of Hebei \\ Medical University, Shijiazhuang, China, ${ }^{4}$ National Health Commission of China (NHC) Key Laboratory of Human Disease \\ Comparative Medicine, Institute of Laboratory Animal Sciences, Chinese Academy of Medical Sciences and Comparative \\ Medicine Center, Peking Union Medical College, Beijing, China
}

Estrogen mainly binds to estrogen receptors (ERs) to regulate menstrual cycles and reproduction. The expression of ERalpha $(E R \alpha)$, ERbeta $(E R \beta)$, and G-protein-coupled estrogen receptor (GPER) mRNA could be detected in ovary, suggesting that they play an important role in estrogen signal transduction in ovary. And many studies have revealed that abnormal expression of estrogen and its receptors is closely related to ovarian disease or malignant tumors. With the continuous development and research of animal models, tissue-specific roles of both ER $\alpha$ and ER $\beta$ have been demonstrated in animals, which enable people to have a deeper understanding of the potential role of ER in regulating female reproductive diseases. Nevertheless, our current understanding of ERs expression and function in ovarian disease is, however, incomplete. To elucidate the biological mechanism behind ERs in the ovary, this review will focus on the role of $E R \alpha$ and ER $\beta$ in polycystic ovary syndrome (PCOS), ovarian cancer and premature ovarian failure (POF) and discuss the major challenges of existing therapies to provide a reference for the treatment of estrogen target tissue ovarian diseases.

Keywords: estrogen, estrogen receptor $\alpha$, estrogen receptor $\beta$, ovary, biosynthesis

\section{INTRODUCTION}

In the female reproductive system, there are two major components, the uterus, which is used for pregnancy, and the ovary, which generates ova. Ovaries are the central organ of female reproduction, providing hormones such as testosterone, inhibin, progesterone, and estrogen, which play crucial roles in menstrual cycle regulation and maintenance of fertility (1). Hormones produced by the ovaries also cause periodic changes in the endometrium, the period of endometrium proliferation corresponding to the follicular phase of the ovary and forms the basis for a successful pregnancy. In particular, estrogen is an important class of steroid hormones that include estrone (E1), estradiol (E2 or 17 $\beta$-estradiol), and estriol (E3) (2), of which E2 is the most abundant and active estrogen. Estrogen exerts a critical influence on female reproduction via the two principal estrogen receptors (ERs), ER $\alpha$ and ER $\beta$. 
Deficient endogenous estrogen production can result in functional reproductive disorders in women, which profoundly influence infertility. Common diseases in women (e.g., polycystic ovary syndrome, endometriosis, breast cancer, and ovarian cancer) are associated with aberrant estrogen-mediated functions and the expression of corresponding ER $\alpha$ and ER $\beta$. A better understanding of the mechanism has been achieved through extensive studies of ERs. Nevertheless, further analyses to reach convincing conclusions and determining efficient precautions remain necessary. This review will focus on the physiological roles of the estrogen and ERs in regulating ovary and current major medications used to stimulate ovarian function.

\section{ESTROGEN AND ERS EXPRESSION PROFILE IN THE OVARY}

\section{Estrogen Synthesis}

Estrogen plays a fundamental role in the development and normal physiological function of the human female reproductive tract, including the ovaries and fallopian tubes. Before puberty, only low concentrations of endogenous estrogen is present in girls; the onset of puberty occurs along with an increased level of hypothalamic gonadotropin-releasing hormone (3). Gonadotropin-releasing hormone triggers the secretion of luteinizing hormone $(\mathrm{LH})$ and follicle stimulating hormone (FSH) from the anterior pituitary gland; subsequently, LH and FSH cause the ovarian follicle to generate large quantities of estrogen. In females, estrogen is produced by locally expressed p450 aromatase from follicular androgens in the ovary and other estrogen-responsive tissues (Figure 1). Specifically, three major forms of endogenous estrogen with estrogenic hormonal activity are present in women: E1, E2, and E3. In pre-menopausal women, E1 and E2 are primarily synthesized in and secreted from the ovarian follicle. $\mathrm{E} 2$ is the most potent and prevalent estrone steroid (70-500 $\mu \mathrm{g}$ daily, depending on the phase of the menstrual cycle); accordingly, E2 is the major product of the overall estrogen biosynthesis process. In postmenopausal women, E1 becomes the most prevalent endogenous estrogen; it is produced by conversion of androstenedione (secreted by the adrenal cortex) to E1 by peripheral tissues (4). E3 is produced in large quantities by the placenta during pregnancy; it is formed from E1 through 16 $\alpha$-hydroxylation (5). The process of differentiation during the embryonic and prenatal period, as well as the maturation of these tissues during puberty, determines fertility in females.

Although circulating estrogen exists in a dynamic equilibrium with metabolic interconversions, E2 is the principal intracellular human estrogen because its potency is substantially greater than that of its metabolites, E1 and E3, at the receptor level (6). It is well known that in the late follicular phase of the menstrual cycle when concentrations of E2 reach a persistently high critical concentration $(\geq 200 \mathrm{pg} / \mathrm{mL})$, a dramatic shift occurs in E2 action, such that feedback changes from negative to positive at both pituitary and hypothalamic levels; after the shift, E2 becomes a positive inducer of the anterior pituitary and triggers it to release more FSH and LH. These increased levels of FSH and $\mathrm{LH}$ stimulate ovarian follicles to produce more E2 (7-9). Following ovulation, E2 concentrations temporarily decrease, but are restored by corpus luteum activity (Figure 1).

\section{ERs Gene, Protein, and Expression in the Ovary}

The levels of ER $\alpha$ and ER $\beta$ expression in different tissues varied greatly. In rats, $\mathrm{ER} \alpha \mathrm{mRNA}$ is mainly expressed in predominant in

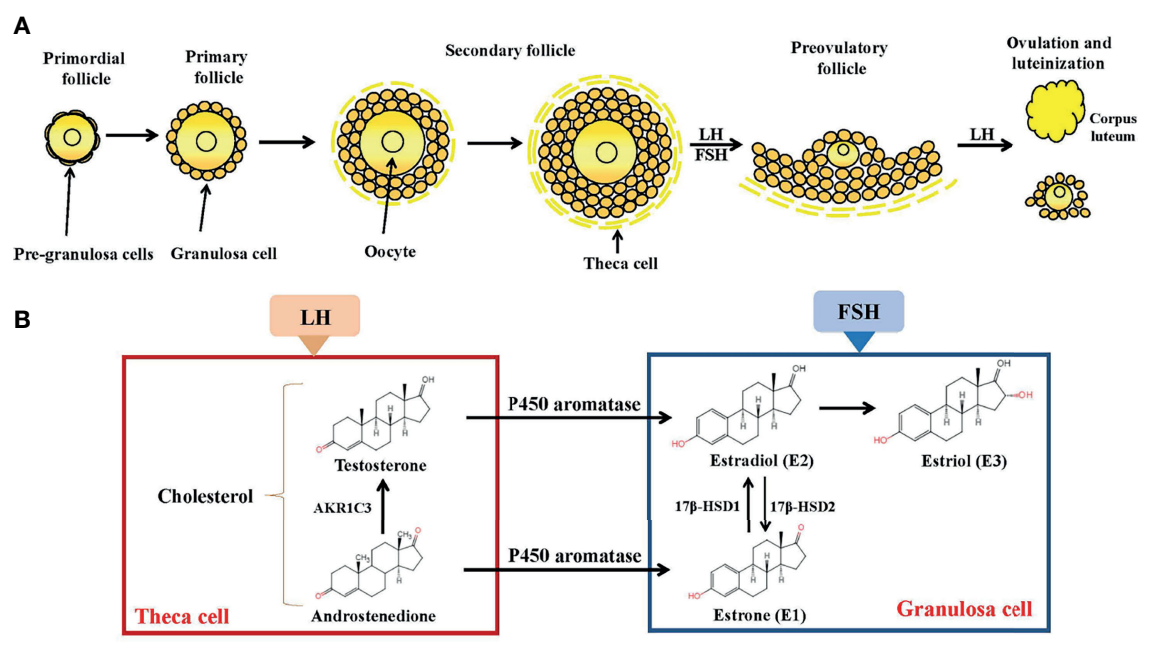

FIGURE 1 | Folliculogenesis and follicular estrogen synthesis. (A) Estrogen biosynthesis in ovarian follicles is known as the 'two-cell-two-gonadotropin system' because both cells (granulosa and theca cells) and gonadotropins (FSH and LH) are indispensable for the generation of estrogen in ovarian follicles. Follicles are mainly composed of oocytes, granulosa cells and theca cells. Folliculogenesis develops from primordial, primary, secondary follicles and preovulatory follicles before ovulation occurs. After ovulation, the corpus luteum activity was restored. (B) Synthesis of estrogen. In theca cells, LH stimulation produces androstenedione and testosterone. In granulosa cells, testosterone is converted by P450aromatase into estradiol. LH, Luteinizing Hormone; FSH, follicle stimulating hormone; AKR1C3, aldo-keto reductase 1C3; 17ßHSD, 17ß-hydroxysteroid dehydrogenase. 
the uterus, mammary gland, testis, pituitary, adipose tissue, kidney and skeletal muscle, while ER $\beta$ mRNA is dominant in the ovary, prostate, lung, cardiovascular and central nervous systems (10-12). For example, the most obvious is that $\mathrm{ER} \beta / \mathrm{ER} \alpha$ in the ovary is much higher than in uterus (11). In human tissues, ERs have two isoforms, $\mathrm{ER} \alpha$ and ER $\beta$. ER $\alpha$ is encoded by ESR 1 gene on chromosome 6q25.1 while ER $\beta$ is encoded by ESR2 on chromosome 14q23.2 (13, 14). Northern blot analysis revealed that $\operatorname{ER} \beta$ transcripts were detected in human testis, thymus, spleen and ovary (14). ER $\alpha$ mainly participates E2 signaling in the uterus, mammary glands, pituitary, skeletal muscle, adipose tissue and bone $(15,16)$.

Furthermore, with the development of research, several discrepancies in ER $\alpha$ and ER $\beta$ are gradually prominent, even in the same tissue, the expressions of $\operatorname{ER} \alpha$ and $\operatorname{ER} \beta$ positions are also different. In the rat ovary, $\operatorname{ER} \beta$ is detectable in granulosa cells of maturing follicles; conversely, ER $\alpha$ is more abundant in the interstitium and theca cells $(17,18)$. ER $\alpha$ and $\operatorname{ER} \beta$ are differentially expressed in human bone, prostate and breast tissue $(15,19,20)$. Both normal and neoplastic human tissues and cell lines express detectable ER $\beta$ mRNA (21-23).

The data of ER expression location in the ovary is obtained by in situ hybridization of premenopausal female reproductive tissue (Table 1). In the human ovary, immunohistochemical studies have shown that $\mathrm{ER} \alpha$ and $\mathrm{ER} \beta$ are differentially expressed in granulosa cells that develop follicles. ER $\beta$ immunoreactivity is found in granulosa cells of growing follicles at all stages from primary to mature follicles, and also in some interstitial gland cells $(15,29)$. $\mathrm{ER} \alpha$ predominantly occurs in the thecal, interstitial gland and germinal epithelium cells. Before the discovery of ER $\beta$, ER was described in 1993 in the ampullary and fimbrial sections of the fallopian tube $(30,31)$. The present observations suggest that estrogen stimulates the proliferation of granulosa cells in small follicles, enhance the sensitivity of granulosa cells to FSH and LH, and modulate the biosynthesis of progestins and cAMP (32). Several studies have also reported GPER mRNA and protein is localized on the ovary $(27,28)$. However, the exact role and mechanism of estrogen in human ovaries remain to be elucidated.

\section{MECHANISM OF ERS ACTION IN THE OVARY}

Estrogen is produced in the ovaries and is present in highest concentrations in this organ. In theory, it continuously saturates and activates homologous receptors and could lead to continuous transcriptional activation. Estrogen signaling pathways are mainly mediated by ER $\alpha$ and ER $\beta$ which located at different chromosomal locations. At the cellular level, they function synergistically or antagonistically, therefore the final cellular outcome will be determined by their cumulative interaction of activation and/or inhibition pathways (33). Numerous mRNA splice variants exist for both receptors in both normal and diseased tissues (34). ER consists of six components: an amino-terminal domain (A/B domain), a DNA-binding domain (DBD; C domain), a hinge region (D domain), a ligand-binding domain (LBD; $\mathrm{E}$ domain), and a carboxy-terminal domain (F domain) (35). ER $\alpha$ and ER $\beta$ share similar structures and they form homodimers (ER $\alpha \alpha / E R \beta \beta)$ or heterodimers $(\mathrm{ER} \alpha \beta)$ upon estrogen binding (36). The aminoterminal $\mathrm{A} / \mathrm{B}$ domains of $\mathrm{ER} \alpha$ have ligand-independent AF-1, while the LBD includes the ligand-dependent AF-2 which is significant in ligand-dependent transcriptional regulation (37). In contrast, ER $\beta$ displays a lower affinity for ERE binding and considerably lower transcriptional activity in the E2-induced ERE-dependent genomic signaling pathway.

ER-mediated genomic pathway can be subdivided into EREdependent and ERE-independent subtypes, and both processes typically occur within hours (34). In the "classical" mechanism of estrogen action, the nuclear ER-estrogen complex directly binds to a specific DNA sequence called the estrogen responsive element (ERE) in the promoter regions of estrogen-responsive genes, then regulates the transcription of these genes (38). Alternatively, the nuclear ER-estrogen complex can bind to ERE sequences indirectly through protein-protein interactions with transcription factors, like activator protein 1 (AP-1) or specificity protein 1 (SP-1) that occur in the promoter regions of ERE sequences. These interactions result in the recruitment of co-regulatory proteins (co-activators or co-repressors) to the promoter, changes in mRNA levels, and the production of proteins that are associated with physiological responses (39-42).

Furthermore, ER $\alpha$ was found to be association with the cell membrane, allowing for rapid 'non-genomic' estrogen signaling. The non-genomic pathway typically involves cytoplasmic proteins, growth factors, and other membrane-initiated signaling pathways (43-45). Alternatively, in addition to hormone-mediated activation, it is now well accepted that ER function can be modulated by extracellular signals in the absence of E2. Polypeptide growth factors, such as epidermal growth factor (EGF) and insulin-like growth factor-I (IGF-I), activate ER and increase the expression of ER target genes in an estrogen-

TABLE 1 | Expression of ERs in normal ovary tissue.

\begin{tabular}{|c|c|c|c|c|}
\hline Tissue & Specific location & Method & Results & References \\
\hline Ovary & the granulosa cells of the developing follicles & Immunocytochemistry & $E R \alpha+; E R \beta+(E R \alpha$ and $\beta$ are differentially expressed $)$ & $(15,24)$ \\
\hline Ovary & pre-antral follicles & Immunohistochemistry & $E R \beta+$ & $(24)$ \\
\hline Ovary & mature antral follicles & Immunohistochemistry & $\mathrm{ER} \alpha+; \mathrm{ER} \beta+$ & (24) \\
\hline Ovary & in the surface epithelium & RT-PCR & $E R \alpha+; E R \beta+$ & (25) \\
\hline Ovary & granulosa cells, endothelial cells & Immunocytochemistry & ER $\beta 2+; E R \beta 4+; E R \beta 5+$ & (26) \\
\hline Ovary & granulosa cells & RT-PCR; Western blotting & GPER+ & $(27,28)$ \\
\hline
\end{tabular}

+ , expressed; ER, estrogen receptor; $R T$-PCR, reverse transcription-polymerase chain reaction. 
independent manner (46). Although the molecular mechanisms involved in ligand independent ER activation have been characterized, the biological role of these processes requires further understanding.

GPER is a novel membrane estrogen receptor responsible for rapid non-genomic estrogen response and transcriptional regulation that activates numerous signal transduction pathways. A study demonstrated that $E R \alpha$ is one of the transcription factors downstream of GPER, suggesting the interaction between nongenomic and genomic estrogen receptors (47).

\section{THE ROLE OF ERS: EVIDENCE FROM ANIMAL MODELS}

The ERKO mice are an optimal biological model to the research work for understanding the physiological action and mechanisms of estrogen action (Table 2). Estrogen via ERs is essential for the establishment and maintenance of pregnancy. As evidenced by the $\alpha$ ERKO mouse model, adult $\alpha E R K O$ female mice are infertile due to hypoplastic uteri and hyperemic ovaries without corpora $(48,49)$. In wild-type rodents, the primary site of estrogen feedback is hypothalamus, where $\alpha$ ERKO females cause increased hypothalamic gonadotrophin releasing hormone $(\mathrm{GnRH})$ secretion, which then manifests as hypergonadotropism, resulting in ovarian cyst formation. Female mice with $\alpha$ ERKO have elevated plasma estradiol and androstendione levels, as well as elevated testosterone levels. In addition, an obvious endocrine sex reversal observed in $\alpha \mathrm{ERKO} /$ $\alpha \beta E R K O$ ovaries, characterized by ectopic expression of HSD17 $\beta 3$, as this enzyme is unique to the testes $(48,50)$.

ENERKI mice are a mutation converts glycine to leucine at residues 525 (G525L) in LBD of $\mathrm{ER} \alpha$, lacking $\mathrm{ER} \alpha$ interaction and response with endogenous estrogen. The phenotypes of ENERKI mice and $\alpha$ ERKO mice are similar. The mammary gland ductal trees of ENERKI mice are rudimentary, with no terminal end bud formation, ductal elongation, branching, or alveolar differentiation (51). ENERKI mice were infertile due to being unable to ovulate normally and had hypoplastic uterine tissues. Phenotypical evaluation of the ENERKI mice has also established that ER $\alpha$ ligand-induced, but not ligandindependent, signaling is critical in female mammary gland and reproductive tract development. Furthermore, ENERKI mice have elevated LH levels, cystic ovaries and high androgen secretion, reminiscent of human polycystic ovary syndrome (PCOS) $(52,53)$. And ENERKI females' granulosa cells are disordered and not encapsulated in follicular structures, similar to certain types of ovarian granulosa cell tumors.

Female mice lacking ER $\beta$ are normally fertile and show normal sexual behavior, but in a continuous mating study, they have reduced litter numbers and sizes compared with wild-type mice (54). This decrease in fertility is the result of impaired follicular maturation and a decrease in the number of follicles responsive to $\mathrm{LH}$. There are fewer corpora lutea in the ovaries of $\beta E R K O$ mice than WT ovary after superovulation, indicating that some follicles failed to rupture and discharge oocytes during the ovulatory hCG surge. ER $\beta$ mediates the stimulating effect of estrogen on granulosa cell proliferation and $\beta E R K O$ mice have an inefficient and rare ovulation response (55). Granulosa cells of $\beta E R K O$ ovaries exhibited an attenuated response to FSH-induced differentiation after PMSG treatment, which is reflected in the insufficient expression of $\mathrm{LH}$ receptors, decreased aromatase activity and reduced estradiol synthesis, accompanied by incomplete expansion of the cumulus-oocyte complex (56). The female mice with ER $\beta$ mutations have normal mammary histology and lactate effectively. These studies might help to determine that $\operatorname{ER} \beta$ is essential for expelling healthy oocytes but not essential for female sexual differentiation, fertility, or lactation.

Briefly, $\alpha$ ERKO and $\beta E R K O$ female mice have an appropriate development female reproductive tract (57). However, lacking sensitivity to estrogen severely affects sexual maturation of the entire reproductive tract in the $\alpha E R K O$ female and ovarian function in $\beta E R K O$ female. Mice lacking ER $\alpha$ and ER $\beta$ exhibit a phenotype similar to $\alpha E R K O$ mice, as female mice are infertile (58). Further investigation is required to determine whether there are potential compensatory and synergistic effects between $\mathrm{ER} \alpha$ and $\mathrm{ER} \beta$.

There are two known forms of nuclear ER, ER $\alpha$ and ER $\beta$, in the tissues of hypothalamic-pituitary-gonadal (HPG) axis. Serum sex hormone levels are strictly regulated by the HPG axis and are associated with follicular growth in the ovaries. The symptoms of female reproductive disease PCOS may result from a disturbance of feedback regulation system of the HPG axis. The regulation of the GnRH neuronal network by E2 involves both negative and positive feedback effects, which together are responsible for producing the ovarian cycle in adult women (59). Estrogen regulates $\mathrm{GnRH}$ neurons to control ovulation in mammals. As GnRH neurons do not express ER $\alpha$, and the positive feedback of estrogen to GnRH neurons is indirect. Mice harboring a neuronspecific $\mathrm{ER} \alpha$ deletion was infertile and lacked estrogen positive feedback, and the ER $\alpha$-expressing neurons have been found to modulate $\mathrm{GnRH}$ neurons located within the periventricular nuclei of the rostral hypothalamus (60). The study has provided evidence to show that the ovulation is mediated by estrogen actions on ER $\alpha$-expressing neuronal afferents to GnRH neurons. Furthermore, ablation of ER $\alpha$ from neurons expressing calmodulin kinase II $\alpha$ using a tamoxifen-based inducible CreLoxP approach displayed that $\mathrm{ER} \alpha$ is a key receptor responsible for acute negative estrogen feedback in the mouse brain (61). However, ER $\beta$ is expressed in GnRH neurons. Global ER $\beta$ mutant mice showed normal patterns of estrogen-induced $\mathrm{GnRH}$ activation and $\mathrm{LH}$ surge secretion. This indicated that ER $\beta$-regulated signaling in $\mathrm{GnRH}$ neurons is not important for estrogen positive feedback (60). Mutant mice with selective deletion of ER $\beta$ and its functional splice variants in $\mathrm{GnRH}$ neurons also suggested that ER $\beta$ has no critical role in acute negative feedback in GnRH neurons $(61,62)$.

Both $\mathrm{ER} \alpha$ and $\mathrm{ER} \beta$ are expressed in the rat pituitary gland, yet diverse lines of evidence indicate that estrogen-induced pituitary changes are presumably mediated by $\operatorname{ER} \alpha(12,63)$. Gieske et al. produced a $\mathrm{ER} \alpha^{\text {flox/flox }} \alpha \mathrm{GSU} \mathrm{U}^{\text {cre }}$ mice line by deleting ER $\alpha$ in pituitary gonadotroph (64). The basal LH and FSH levels of female pituitary-specific ER $\alpha$ knockout mice were not elevated 
and their ovulation ability was comparable to that in controls, their estrous cycles were irregular and infertile, suggesting that the LH surge is mistimed, attenuated, or absent. Taken together, $\mathrm{ER} \alpha$ in the pituitary gonadotroph is required for estrous cyclicity and fertility in females. In addition, these findings support that the pituitary is not the primary target of negative estrogen feedback in mice, but rather the hypothalamus, compared to the $\mathrm{ER} \alpha{ }^{-/-}$phenotype.

In another study, however, estrogen positive and negative feedback was disrupted in female mice lacking $E R \alpha$ in the pituitary gonadotroph (PitESR1KO) (65). Female PitESR1KO mice were subfertile or infertile, had higher serum LH levels than wild-type, along with a lack of surges in LH values and regular estrous cycles. Some hemorrhagic cystic follicles were also noted in these mice.

Due to the varied phenotypes reported in pituitary-specific $\mathrm{ER} \alpha \mathrm{KO}$ mouse models, Arao et al. develop a unique model that reintroduces $\mathrm{ER} \alpha$ expression exclusively in the pituitary on the background of a global ER $\alpha$-null (PitERtgKO) mouse (66). The findings suggested that serum E2 and LH levels were normalized in PitERtgKO females. While PitERtgKO female mouse caused a more severe cystic and hemorrhagic phenotype than observed in ER $\alpha$ KO females, implying that anomalous sporadic LH secretion is an important factor to induce severe ovarian phenotype. The results also further suggested that pituitary ER $\alpha$ is involved in negative feedback regulation of estrogen and hypothalamus ER $\alpha$ is required for precise control of LH secretion (66).

Wang et al. reported that GPER expression in hamster ovaries depends on the estrous cycle, with GPER mRNA and protein abundance in the granulosa and theca cell layers peaking on day 3 of the estrus cycle and decreasing on day 4 (67). GPER has been shown to regulate the E2-mediated stimulation of primordial follicle formation in the hamster ovary (68). However, the GPER KO mouse model exhibits normal fertility and reproduction, which may explain the lack of particularly strong effects of GPER on normal reproductive physiology (69). Due to species differences, reproductive data from rodents may not apply to humans.

ER knock-out models suggest that ER $\alpha$ plays an active role in the reproductive system, and ER $\beta$ mediates estrogen stimulation of granulocyte proliferation, which is important during ovulation, and the role of GPER appears to be less significant than that of $\mathrm{ER} \alpha$ and ER $\beta$. In general, studies using animal models have highlighted the importance of $\operatorname{ER} \alpha$ and $\operatorname{ER} \beta$ signaling in the ovary and the effect of ERs on the gonadal axis on the ovary.

\section{ERS AND THE MAIN PATHOLOGICAL CONDITIONS OF OVARY}

ER is a marker of ovarian disease in the numerous conditions affecting the ovarian functions. Therefore, the mechanism of ER involved in inducing ovarian disease and cancer cell growth should be further studied (Figure 2).

\section{PCOS}

PCOS is a state of unbalanced steroid hormone production and activity that affects approximately $4 \%-18 \%$ of women of reproductive age worldwide (71). The most common phenomena are anovulation (or oligo-ovulation) and endometrial changes, which typically result in female infertility. According to the conclusion of the 2003 Rotterdam consensus workshop, the clinical manifestations of PCOS include low or no ovulation, hyperandrogenism, and obesity (72). Insulin resistance and elevated serum $\mathrm{LH}$ levels are also common characteristics of PCOS. The criteria included a wider range of symptoms of ovarian dysfunction than the previous NIH classification of 1990. And it has been recognized that not all females with the disease have the biochemical and clinical features defined by PCOS, and that some women with the syndrome have regular cycles, or do not have excess androgens, but will show evidence of ovarian dysfunction (73).

Unlike higher testosterone and lower progesterone levels, estrogen levels in women with PCOS are typically similar to those of healthy women (74). ER $\beta$ stimulates follicular growth, induces the expression of specific genes, and increases the number of ovulated oocytes. Disruption of the ER $\beta$ gene, therefore, would be expected to have effects on ovarian function and subsequent fertility in the female. In contrast, ER $\alpha$ inhibited ovulation, presumably through effects on the HPG axis and uterine growth (75) (Figure 2). The mechanism of estrogen deficiency or disrupted estrogen synthesis by PCOS remains a longstanding challenge. Upregulation and activation of the WNT2/ $\beta$-catenin pathway was reportedly tightly associated with estrogen deficiency in PCOS cumulus cells (76). Moreover, the mRNA expression levels of ER $\alpha$ and ER $\beta$ in cumulus cells from patients with PCOS are significantly lower than those from healthy controls (75), and considerable alterations in the expression levels of ER $\alpha$ and $\operatorname{ER} \beta$ are also found in theca and granulosa cells (77); taken together, these findings suggest abnormal folliculogenesis in patients with PCOS.

Interestingly, women with PCOS possess various endometrial abnormalities. Women with PCOS present with alterations in the hypothalamic-pituitary-ovarian axis, which results in persistent circulating levels of estrogen, and complex effects on the endometrium, leading to implantation failure and proliferative aberrations (78). Several endometrial markers associated with the PCOS phenotype have been carried out, explaining some of the adverse endometrium-related clinical manifestations. ER may be the most prominent marker in women with PCOS, as the expression of ER is reportedly increased in the stroma and glandular epithelium of women with PCOS (79-83). Moreover, endometrial $\mathrm{ER} \alpha$ immunostaining is reportedly higher in the stroma and epithelium of women with PCOS during the proliferative phase of the menstrual cycle $(83,84)$, but some studies have shown no alterations in ER expression among patients with PCOS (81). Recent studies have demonstrated that, compared with body mass index-matched controls, proliferative endometrium in women with obesity who have PCOS exhibits lower mRNA levels of ER $\alpha$ and ER $\alpha 36$, as well as a lower $\mathrm{ER} \alpha / \mathrm{ER} \beta \mathrm{mRNA}$ ratio (85). It has been reported that the endometrium from PCOS-like rodents and patients with PCOS is morphologically normal, but exhibits structurally and biochemically abnormal responses to hormone stimulation; 
TABLE 2 | Animal models of estrogen receptors in the hypothalamic-pituitary-ovarian axis.

\begin{tabular}{|c|c|c|c|c|c|c|c|}
\hline Models & $\begin{array}{l}\text { Estrous } \\
\text { cycle }\end{array}$ & $\begin{array}{l}\text { Ovarian } \\
\text { cyst }\end{array}$ & Fertility & $\begin{array}{l}\text { Androgen } \\
\text { levels }\end{array}$ & LH levels & Notes & References \\
\hline $\begin{array}{l}\alpha E R K O \\
\text { mouse }\end{array}$ & Irregular & YES & Infertile & $\begin{array}{l}\text { Androstendione } \\
\text { levels } \uparrow ; \\
\text { testosterone } \\
\text { levels } \uparrow\end{array}$ & $\begin{array}{l}\text { Circulating LH } \uparrow \text {; plasma LH levels } \\
\text { were significantly lower than } \\
\text { ovariectomized wild-type females }\end{array}$ & $\begin{array}{l}\text { Hypoplastic uteri; hyperemic ovaries; E2 } \\
\text { levels } \uparrow\end{array}$ & $(48,49)$ \\
\hline $\begin{array}{l}\alpha \beta E R K O \\
\text { mice }\end{array}$ & NA & NA & Infertile & $\begin{array}{l}\text { Plasma } \\
\text { testosterone } \\
\text { levels } \uparrow\end{array}$ & $\begin{array}{l}\text { Serum LH levels was higher than } \\
\alpha E R K O \text { females }\end{array}$ & $\begin{array}{l}\text { Normal reproductive tract; no corpora lutea } \\
\text { were observed; apparent sex reversal }\end{array}$ & $(48,50)$ \\
\hline ENERKI mice & NA & YES & Infertile & $\begin{array}{l}\text { Testosterone } \\
\text { levels } \uparrow\end{array}$ & Serum LH levels $\uparrow$ & $\begin{array}{l}\text { Have hypoplastic uterine tissues; } \\
\text { rudimentary mammary gland ductal trees; } \\
\text { E2 levels } \uparrow\end{array}$ & $(51)$ \\
\hline$\beta E R K O$ & NA & No & $\begin{array}{l}\text { Exhibit } \\
\text { variable } \\
\text { degrees of } \\
\text { Subfertility }\end{array}$ & $\begin{array}{l}\text { Plasma } \\
\text { testosterone } \\
\text { levels } \uparrow\end{array}$ & Exhibited wild type-like levels & $\begin{array}{l}\text { Aromatase activity } \downarrow \text {; estradiol synthesis } \downarrow \text {; } \\
\text { have normal mammary histology }\end{array}$ & $(53,55)$ \\
\hline $\begin{array}{l}\text { A neuron- } \\
\text { specific ER } \alpha \\
\text { mutant } \\
\text { mouse }\end{array}$ & $\begin{array}{l}\text { Failed to } \\
\text { exhibit } \\
\text { estrous } \\
\text { cycles }\end{array}$ & NA & Infertile & NA & Basal LH levels are not elevated & $\begin{array}{l}\text { Lack estrogen positive feedback; have } \\
\text { dilated, fluid-filled uteri; increased numbers } \\
\text { of antral follicles; ack of corpora lutea }\end{array}$ & $(60,61)$ \\
\hline $\begin{array}{l}\text { neuron- } \\
\text { specific ER } \beta \\
\text { null mice }\end{array}$ & $\begin{array}{l}\text { Normal } \\
\text { estrous } \\
\text { cycles }\end{array}$ & NA & $\begin{array}{l}\text { Impairment } \\
\text { of fertility }\end{array}$ & NA & $\begin{array}{l}\text { Increase in LH secretion after } \\
\text { ovariectomy }\end{array}$ & Normal negative feedback & $(61,70)$ \\
\hline $\begin{array}{l}\text { ERo } \alpha^{\text {flox/flox }} \\
\alpha G S U^{\text {cre }} \\
\text { mice }\end{array}$ & Irregular & NA & Infertile & NA & $\begin{array}{l}\text { Basal serum LH levels were not } \\
\text { elevated }\end{array}$ & $\begin{array}{l}\text { Maintain a basal level of serum FSH; their } \\
\text { ovulatory capacity is comparable to } \\
\text { controls; }\end{array}$ & (64) \\
\hline PitESR1KO & Irregular & YES & $\begin{array}{l}\text { Subfertile or } \\
\text { infertile }\end{array}$ & NA & Serum LH levels $\uparrow$ & $\begin{array}{l}\text { A decrease in the number of litters and } \\
\text { size of the litters; }\end{array}$ & (65) \\
\hline PitERtgKO & Irregular & YES & NA & $\begin{array}{l}\text { Testosterone } \\
\text { levels } \uparrow\end{array}$ & Serum LH levels were normal & $\begin{array}{l}\text { Pituitary ER } \alpha \text { is involved in negative } \\
\text { feedback regulation of estrogen; an } \\
\text { anomalous sporadic LH secretion profile }\end{array}$ & (66) \\
\hline $\begin{array}{l}\text { GPER KO } \\
\text { mouse }\end{array}$ & Regular & NO & Fertility & NA & Serum LH levels were normal & $\begin{array}{l}\text { Normal function of the HPG axis; ovaries } \\
\text { developed normally }\end{array}$ & (69) \\
\hline
\end{tabular}

$\uparrow=$ upregulated; $\downarrow=$ downregulated; NA: not available or not assessed. ER, estrogen receptor; GPER, G-protein-coupled estrogen receptor; FSH, follicle stimulating hormone; $L H$, luteinizing hormone; HPG, hypothalamic-pituitary-gonadal.

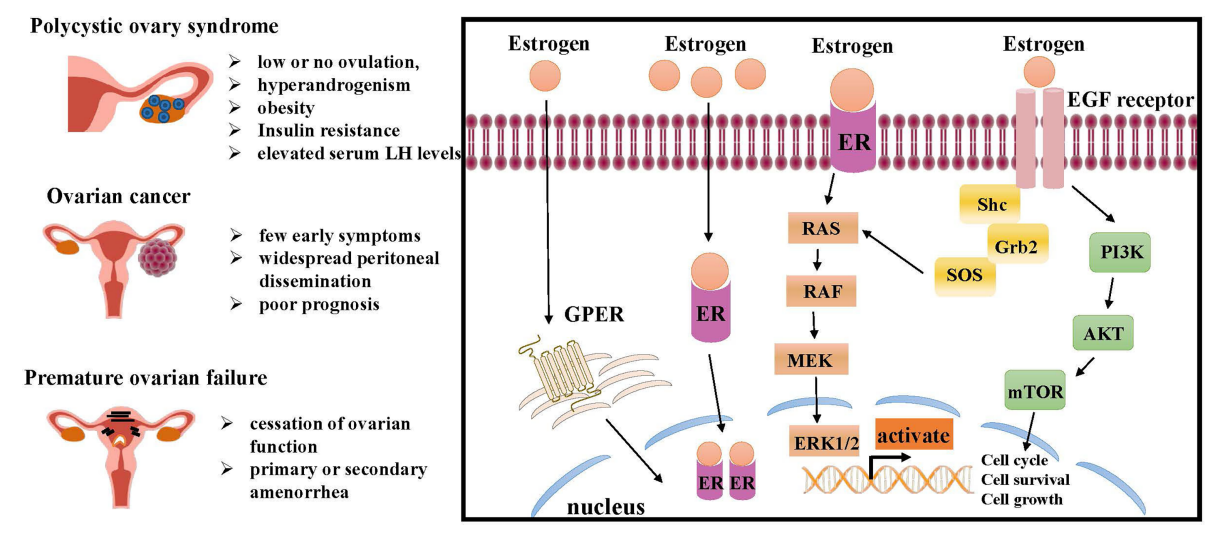

FIGURE 2 | Molecular pathways of ER regulation in ovarian lesions, like PCOS, ovarian cancer and premature ovarian failure (POF). The interaction of estrogen and ER can initiate intracellular signaling cascades leading to downstream activation of MAPK signaling and PI3K/AKT signaling, both of which are critical for cell growth and proliferation. Estrogen also promotes ovarian disease by regulating GPER. ER, estrogen receptor; RAS, renin-angiotensin system; RAF, residual adversarial fusion; MEK, mitogen-activated protein kina; ERK, extracellular regulated kinase; Grb, cytotoxic protease granzyme B; EGF, epidermal growth factor; PI3K, phosphoinositide 3-kinase; AKT, mTOR, mammalian target of rapamycin; GPER, G-protein-coupled estrogen receptor. 
uterine E2-regulated glycolysis via $\mathrm{ER} \alpha$ activation may contribute to successful implantation and the establishment of pregnancy, as E2 is widely regarded as a master regulator of endometrial cell proliferation $(86,87) . \mathrm{ER} \beta^{-/-}$mice have defective ovulation reminiscent of PCOS in humans (88). Studies focused on polymorphisms in ER genes have shown no associations between the polymorphisms PvuII and XbaI in ER $\alpha$ and the presence of PCOS (89). In contrast, another study reported that ER $\alpha$ rs9340799 was associated with susceptibility to PCOS in Pakistani women in a sequencing analysis of DNA samples from 96 patients with genetically unrelated PCOS and 96 controls (90). Jiao et al. found that the GA genotype of rs1999805 in ER $\alpha$ increased the risk of PCOS in the Chinese population (91). Furthermore, a study evaluating polymorphisms in $\operatorname{ER} \beta$ gene demonstrated that the ER $\beta$ gene $+1730 \mathrm{G} / \mathrm{A}$ polymorphism may be associated with pathophysiologic aberrancies observed in patients with PCOS (92).

A normal endocrine feedback loop between organs of the HPG axis exerts a critical influence on reproductive potential. ERs are necessary for the normal function of the hypothalamicpituitary-ovarian axis. Attenuated E2 negative feedback action by neuronal $\mathrm{ER} \alpha$ of the mediobasal hypothalamus may lead to GnRH hypersecretion, and thus LH excess, contributing to ovarian hyperandrogenism in PCOS.

There are a number of reports that the hypothalamic-pituitaryadrenal axis plays a role in the development of PCOS. For example, patients with congenital adrenal hyperplasia possess features of PCOS, are characterized by elevated LH levels and ovarian hyperandrogenism (93). Notably, studies have shown that ER $\alpha$ and ER $\beta$ are expressed in the hypothalamus, where they induce $\mathrm{GnRH}$ release and upregulate anterior pituitary $\mathrm{GnRH}$ receptor expression, thereby promoting the positive regulation of the hypothalamic-pituitary axis by estrogen and maintaining normal ovulation $(94,95)$. Considering the direct and indirect effects of estrogen on follicle development, maturation and ovulation mediated by $\mathrm{ER} \alpha$ and $\mathrm{ER} \beta$, it is expected that polymorphisms in $\mathrm{ER} \alpha$ and/or ER $\beta$ play a role in the persistent anovulation in PCOS. However, studies on SNPs in estrogen signaling and susceptibility to PCOS have been inconsistent. Zhou et al. concluded that no significant association between ER $\alpha$ rs2234693, RS9340799, and ER $\beta$ RS4936938 variants and PCOS (96). But we should note that although no statistical significance was found, the rate of RS2234693 polymorphism in ER $\alpha$ in patients with PCOS tended to be higher than in control women.

Studies provide evidence that estrogen may induce its effect on the adrenal gland through receptor-mediated mechanism (97). Although ovaries are the major source of increased androgens in PCOS, studies have found that the adrenal glands also contribute to hyperandrogenism in the syndrome. Approximately 20-33\% of PCOS patients present with an excess of adrenal androgens, which is primarily detected by elevated levels of dehydroepiandrosterone sulfate (98). Studies have illustrated that circulating adrenal androgens serve as precursors of ovarian androgens via intraovarian conversion, and that if serum adrenal androgen levels are elevated, it is possible to induce polycystic ovaries functionally and morphologically (99). In contrast, data indicate that in PCOS, the ovaries promoted adrenal androgen overproduction $(100,101)$. Thus, in PCOS, the ovaries and adrenal glands may be able to interact in a bidirectional manner in addition to the traditional regulation exerted by the hypothalamus and pituitary on either peripheral gland. Nevertheless, the relationship between ERs expression and human PCOS and adrenal gland remains to be further investigated.

Several researches have examined a possible association between GPER and oocyte maturation. For instance, Pang and colleagues treated Atlantic croaker oocytes with E2 and G-1 (GPR30 ligand), indicating GPER maintained oocyte meiotic arrest by activating adenylate cyclase (102). The high expression GPER mRNA in carp oocytes showed the inhibitory effect of E2 on oocyte maturation (103). Peyton et al. also confirmed this idea in zebrafish experiments (104). Subsequently, the relationship between GPER and follicular dysplasia was further revealed in recent studies. Zang et al. analyzed the differences in GPER expression between patients with PCOS and women without PCOS (28). The data indicated the GPER mRNA and protein levels of granulosa cells in PCOS patients were higher than those in the control group at the germinal vesicle stage. Therefore, E2 may be involved in inhibiting oocyte meiosis through GPER. This results in abnormalities oocyte maturation, increased follicular density and augmented androgen synthesis, which is a confluence of factors that induce PCOS.

\section{Ovarian Cancer}

Among gynecological malignancies, epithelial ovarian cancer is the most common cause of gynecological cancer death and it is the seventh most common female cancer in the world (105). Every year around the world, 230000 women will be diagnosed and 150000 will die (106). Although many efforts have been made to elucidate the etiology of ovarian cancer and the molecular mechanisms involved in ovarian cell proliferation, the disease remains poorly understood.

The expression levels of ER $\alpha$ are implicated in estrogendependent proliferation, invasion and response to endocrine therapy in ovarian cancer (107). ER $\alpha$ is a direct target of the tumor suppressor microRNA (miR)-206, and the introduction of miR-206 mimics inhibits cell proliferation and invasion of ER $\alpha$ positive ovarian cancer cell lines, CAOV-3 and BG-1 (108). The effects of $\mathrm{E} 2$ on cancer progression can be mediated by coding RNAs and non-coding RNAs (ncRNAs). Studies have indicated that three long non-coding RNAs (TC0100223, TC0101686 and TC0101441) are abnormally expressed in ER $\alpha$-positive epithelial ovarian cancer (EOC) tissues, suggesting that they may have potential for cancer progression (109). And TC0101441 is considered to be an independent prognostic factor for overall survival (109). In vitro studies have used cDNA microarrays to confirm changes in gene expression in E2-treated PEO1 cells (an ER-positive, estrogenresponsive ovarian cancer cell line); the activation of ER $\alpha$ mediated transcription was shown to be responsible for the observed changes in gene expression, as well as the estrogendriven growth of epithelial ovarian carcinoma, whereas ER $\beta$ played no meaningful role (110). 
The level of ER $\alpha$ mRNA in malignant tumors is higher than that in benign tumors, while $\operatorname{ER} \beta$ mRNA in benign is higher than in malignant tumors. Therefore, we hypothesize that $\operatorname{ER} \beta$ may have the opposing effects on ovarian cancer. ER $\beta$ levels and/or the $E R \beta / E R \alpha$ ratio decrease along with the development of ovarian cancer, indicating that loss of ER $\beta$ expression affects carcinogenesis. Treatment with the ER $\beta$ agonist DPN or reintroduction of ER $\beta$ results in notably slower cell growth in both ovarian cell lines SKOV3 and OV2008, and xenografts (111, 112). ER $\beta$ decreased the frequency of $S$ phase cells and increased the cells in G2/M phase cells. At the molecular level, the inhibitory effects of ER $\beta$ are mediated via the low expression levels of total retinoblastoma ( $\mathrm{Rb})$, phosphorylated $\mathrm{Rb}$ and phospho-AKT cellular content as well as cyclins D1 and A2, accompanied by a more than 10-fold increase of cyclindependent kinase inhibitor p21 (WAF1) transcript levels and upregulation fibulin 1c $(112,113)$. In addition, part of the antiproliferative action of ER $\beta$ can be explained the direct effect of $\mathrm{ER} \beta$ on ER $\alpha$ by strongly inhibiting its expression and activity.

In the normal ovary, the levels of ER $\beta$ are high, being ER $\beta 1$, $E R \beta 2$, and ER $\beta 5$ the most represented isoforms (114). Different ER $\beta$ isoforms may have different roles. Patients with cytoplasmic ER $\beta 2$ expression have markedly worse, the 5-year survival rate of patients with serous ovarian cancer expressing cytoplasmic ER $\beta 2$ was $32 \%$ lower than that of negative patients (115). Cytoplasmic ER $\beta 2$ expression was also reported to be associated with chemoresistance. These findings suggested that the sudden diminish in ovarian estrogen might, confer a more aggressive phenotype by the modulation of ER $\beta 2$ status, and ultimately contribute to ovarian cancer development.

GPER mRNA is expressed in both benign and malignant ovarian tumors, but GPER mRNA is overexpressed in one-third of malignant tumors (116). GPER is localized in the nucleus and cytoplasm of the biopsy tissues of serous and mucinous ovarian adenocarcinoma. GPER is also expressed in certain cell lines, such as SKOV-3, OVCAR-3, and OVCAR5, and is abundantly coexpressed with ER $\alpha$ and ER $\beta$ in the SKOV 3 cell line $(117,118)$. GPER regulates the expression of c-fos and cyclin D1 proteins as well as cancer cell invasion and metastasis factors. In ER $\alpha$-positive BG-1 ovarian cancer cells, GPER mediated growth response to estrogen and G-1 through activation of the EGFR pathway (119). Atrazine is one of the most common pesticide contaminants in groundwater and surface water $(120,121)$. In ovarian cancer, atrazine stimulates the expression of multiple estrogen target genes and the proliferation of ovarian cancer cells through the participation of GPER and ER $\alpha$ (122). On cursory consideration, the role of GPER in ovarian cancer may require the co-expression of ER $\alpha$. On the opposite hand, it has been reported that GPER stimulation in the opposite way, inhibiting the development of cancer. G-1 is a selective GPER agonist that can inhibit the G2/M cell cycle progression and promote apoptosis to control the proliferation of ovarian cancer cells (117).

\section{POF}

POF is a heterogeneous condition clinically defined as cessation of ovarian function, with elevated gonadotropins and low estrogen levels under the age of 40 years, presenting approximately $1 \%$ of women of reproductive age $(123,124)$. Recently, the term primary ovarian insufficiency (POI) has been proposed to scientifically describe the state of ovarian function (125). It is characterized by the occurrence of primary or secondary amenorrhea (126). Although it has an iatrogenic or spontaneous etiology, to date, there is no effective treatment to restore ovulation function. However, underlying genetic abnormalities may still be associated with POF, and sequence variations in genes involved in estrogen metabolism may lead to ovarian dysfunction. Given that initial follicular pool size and follicular recruitment rates are associated with age at menopause, genetic variants in sex hormone receptor genes can be considered important risk factors to POF development.

The results related to the distribution of ER $\alpha$ PvuII and XbaI genotypes in patients with POF are contradictory. Bretherick et al. have uncovered in fifty-five POF patients, compared with 107 women from the general population, and 27 women who had proven fertility after age 37, an association between the polymorphic C allele of PvuII polymorphism in ER $\alpha$ gene and secondary POF risk (127). In keeping with this result, recently, M'Rabet et al. found a positive association of the CC-allele of the $P v u I I$ polymorphic variant in ER $\alpha$ gene to women suffering from infertility (128). Further, Cordts et al. associated the presence of the C allele of ER $\alpha$ PvuII polymorphism (rs2234693) with POF in Brazilian population, and none of the ER $\beta$ polymorphisms evaluated were associated with POF (129). These findings could be due to the decreased of ER $\alpha$ transcription and receptors number in the presence of $\mathrm{C}$ allele in $P v u I I$ site, which impacts the estrogenic response of tissues, leading to low levels of nuclear transcription factors, allowing apoptotic events with multiple estrogen-responsive target tissues to occur.

Other investigators also have reported the relation of $\mathrm{ER} \alpha$ genetic variant and POF. The $\mathrm{X}$ allele of $\mathrm{XbaI}$ and specific haploand diplotype of $P v u I I$ and $X b a I$ polymorphisms were associated with a marginally reduced risk of POF occurrence (130). On the other hand, A study detected ER $\alpha$ gene polymorphisms by MGB primer/probe taqman assay from 126 idiopathic POF patients and 221 post-menopausal controls (131). As is shown in the results, a significantly higher frequency of TT genotypes was observed in the POF patients among the ER $\alpha$ PvuII polymorphisms assessed. When the POF patients were further divided into the primary and the secondary POF groups, secondary POF had a higher prevalence of TT genotype than the control. Indeed, the ER $\alpha$ gene polymorphisms may be associated with the risk of idiopathic POF. Overall, ERs could be involved in the pathogenesis of ovarian failure but, to strengthen this hypothesis, more studies are needed to confirm these results.

\section{DRUGS POTENTIAL FOR TREATING OVARIAN DISORDERS}

Estrogen mediate cell proliferation in both normal and malignant cells; therefore, ER antagonists that can inhibit transcription by promoting the binding of co-repressors to the ERE are useful for the prevention of proliferation in malignant tissues. Mixed agonist-antagonists, such as tamoxifen and 
raloxifene, have distinct pharmacological effects on estrogen target tissues (132). Transcriptional activation of ER $\alpha$ is mediated by AF- 1 in the $\mathrm{N}$ terminal and AF- 2 in LBD, which is needed by the binding of $\mathrm{ER} \alpha$ to cofactors (133). AF-1 activity is regulated by the phosphorylation of Ser118 through the growth factor signaling pathway, whilst the activity of AF-2 responds to ligand binding $(134,135)$. Agonist binding triggers AF-2 activity, but the binding antagonist does not (136). Tamoxifen has a weak agonistic activity. This mild agonistic behavior is caused by phosphorylation of serine 305 of ER $\alpha$ by protein kinase A (PKA) (137). By contrast, human ER $\beta$ lacks AF1 domain activity and is therefore completely dependent on ligand-dependent AF-2 (138). The major determinant of the weak agonist response to tamoxifen is the AF- 1 domain of ER $\alpha$ rather than the AF-1 domain of ER $\beta$, which explains the different responses to anti-estrogen tamoxifen (139). In addition, antiestrogen raloxifene also can block the action of ER by blocking the interaction of AF-2 with p160 coactivator. These drugs are regarded as selective estrogen receptor modulators (SERMs). The use of SERM-targeted ER may be an appropriate approach for the treatment of associated endocrine diseases.

Clomiphene citrate (CC) is another SERM which has ER agonist and antagonist properties, acting as an estrogen agonist at low endogenous estrogen concentrations, otherwise primarily as a competitive antagonist of ER $(140,141)$. CC is metabolized in the liver and excreted in the stool with a relatively long half-life of 5-7 days (142). CC is highly effective in promoting ovulation in women with PCOS and is recommended as the most used medication for most anovulatory or oligo-ovulatory infertility. And CC induced ovulation in women with PCOS is accompanied by increased secretion of LH and FSH by the pituitary gland and enhanced estrogen secretion (143). It is believed that CC affects hypothalamic ER $\alpha$ which implies enhanced secretion of hypothalamic GnRH pulses, thereby increasing the pulse frequency of $\mathrm{LH}$ to promote ovulation (144). Although there is some data regarding its potential harmful effects like affecting endometrial thickness $(145,146)$. A randomized multicenter trial comparing CC, metformin, and a combination of two drugs in patients with PCOS found that the conception rate was significantly higher in the clomiphene group than in the metformin group (147).

Aromatase, also known as CYP19A1, is responsible for the aromatization of androgen to estrogen. Given that aromatase inhibitors significantly reduce systemic estrogen concentrations, researchers have used aromatase inhibitors to induce ovulation by preventing negative feedback of estrogen on FSH (148). Studies have shown that the aromatase inhibitor letrozole is effective in inducing ovulation and increasing follicle recruitment in patients with polycystic ovary syndrome with few side effects (149). Compared with patients who exhibited progression of ovarian cancer, tumors from stable patients (using CA125 marker criteria of which response is associated with ER expression in a phase II trial of letrozole in ovarian cancer) showed significantly lower expression levels of several estrogenresponsive genes, which were demonstrated to be ER $\alpha$ dependent and upregulated by $\mathrm{E} 2$ in the PEO4 ovarian cancer cell line; moreover, higher aromatase expression has been observed in stable patients $(150,151)$. Legro et al. conducted a trial in which 750 women with PCOS were randomly assigned to receive letrozole or clomiphene according to modified Rotterdam criteria and demonstrated that letrozole was superior to CC in patients with PCOS, resulting in recommendation to switch from $\mathrm{CC}$ to letrozole as the first line agent for ovulation induction in this setting (152).

Oral contraceptives (OCs) are used to treat hirsutism, acne, menstrual irregularities, and irregular menses and of malepattern alopecia. We should note that adolescents with PCOS may experience distress due to clinical manifestations of hyperandrogenemia. Thus, OC pills could be used as a first line therapy for young women with PCOS who have no reproductive requirements (153). OCs have been proven to contain low doses of estrogen and progestin which regulate ovulation by inhibiting the hypothalamic-pituitary-ovarian axis (154). The positive effect of OCs in the treatment of PCOS is predominantly attributed to the reduction of $\mathrm{LH}$ secretion, inhibition of ovarian and adrenal androgen secretion, which decreases free testosterone levels and increases sex hormonebinding globulins production in the liver (155).

The effectiveness of PCOS treatment depends on the dose of estrogen in the contraceptive drug. In general, long-term follow-up and treatment with combined OC is required and at least 6 months of OC therapy is needed to detect improvement in hirsutism or acne in women with PCOS (156). Metformin, an insulin sensitizer, is used to treat PCOS in women with modulated hyperinsulinemia, androgen levels, and menstrual irregularities in women with PCOS (157). However, OCs and metformin, as well as oral contraceptives alone, were reported to be superior to metformin alone in reducing free testosterone levels (158). Contraceptive pills can reduce the risk of endometrial cancer in a long lasting period due to the protective effect of progestin, which is present in OCs $(159,160)$. However, some studies have provided evidence that OCs may impair tissue insulin sensitivity and increase the potential risk of thrombosis and metabolic disease $(154,155)$.

\section{CONCLUSION}

Although it has long been suspected that ERs play an important role in in the ovaries, and there is strong evidence that this is the case in many models, the role of estrogen and its receptors in human disease is extraordinarily complex. The co-dependent, redundant, and independent aspects of E2 signaling through both nuclear and membrane-associated ERs are complex and specific to particular cell types, tissues, ligands, and diseases (161). The relative levels of synthesis of ERs and ER variants can also have profound effects on the dynamic and integrated network of cellular events, both in terms of physiology and pathophysiology, in a tissue-specific manner (162). Finally, ER signaling depends on coregulators. Thus, distinct posttranslational modifications modulate unliganded or liganded ER functions at each level, and can alter ligand pharmacology $(163,164)$. GPER inhibits oocyte meiosis to induce polycystic 
ovary syndrome, and some studies have also shown that GPER is involved in the occurrence of ovarian cancer, but the effect of GPER on ovaries is not mainstream. We mainly review the dominant role of $E R \alpha$ and $E R \beta$ in ovarian diseases. The expression levels of ER $\alpha$ and ER $\beta$ are significantly altered in PCOS and ovarian cancer, and the polymorphism of $E R \alpha$ gene is associated with POF.

There is mounting evidence suggesting that changing the ratio of $E R \alpha / E R \beta$ expression may play a key role in tumor development and progression. In fact, pharmacological activated or inhibited of ER $\alpha$ and/or ER $\beta$ has provided the basis for treating many diseases. Studies targeting ER $\beta$ and ER $\alpha$ provide a method to search for novel specific SERMs. But Long-term estrogen treatment-related adverse events induced by SERM treatment should be closely monitored as well; identifying ideal SERMs that can exert favorable tissue-selective estrogenic agonist activities on target tissues, while remaining neutral with respect to $\mathrm{ER}$ and anti-estrogenic activities in the reproductive system, is the future direction of research in this field $(165,166)$. Moreover, in order to better understand the complex regulatory mechanisms of ERs actions in women, it is necessary to build a database of female reproductive diseases. Because most knowledge about the role of ERs in disease has been obtained through animal studies.

In this paper, we discuss animal disease models and the causes of different ovarian diseases that provide insight into the roles of estrogen and its receptor in the female ovary. Also, an overview of available evidence indicating a potential role of ERs as a diagnostic or therapeutic target in reproductive

\section{REFERENCES}

1. Colvin CW, Abdullatif H. Anatomy of Female Puberty: The Clinical Relevance of Developmental Changes in the Reproductive System. Clin Anat (2013) 26:115-29. doi: 10.1002/ca.22164

2. Boon WC, Chow JD, Simpson ER. The Multiple Roles of Estrogens and the Enzyme Aromatase. Prog Brain Res (2010) 181:209-32. doi: 10.1016/S00796123(08)81012-6

3. Aksglaede L, Juul A, Leffers H, Skakkebaek NE, Andersson A-M. The Sensitivity of the Child to Sex Steroids: Possible Impact of Exogenous Estrogens. Hum Reprod Update (2006) 12:341-9. doi: 10.1093/humupd/dml018

4. Simpson ER, Misso M, Hewitt KN, Hill RA, Boon WC, Jones ME, et al. Estrogen-the Good, the Bad, and the Unexpected. Endocr Rev (2005) 26:322-30. doi: 10.1210/er.2004-0020

5. Cui J, Shen Y, Li R. Estrogen Synthesis and Signaling Pathways During Aging: From Periphery to Brain. Trends Mol Med (2013) 19:197-209. doi: 10.1016/j.molmed.2012.12.007

6. Iliopoulos D, Hirsch HA, Wang G, Struhl K. Inducible Formation of Breast Cancer Stem Cells and Their Dynamic Equilibrium With non-Stem Cancer Cells via IL6 Secretion. Proc Natl Acad Sci (2011) 108:1397-402. doi: 10.1073/pnas. 1018898108

7. Vollman RF. The Menstrual Cycle. Major Probl Obstet Gynecol (1977) 7:1-193.

8. Knobil E. The Neuroendocrine Control of the Menstrual Cycle. Recent Prog Horm Res (1980) 36:53-88. doi: 10.1016/B978-0-12-571136-4.50008-5

9. Treloar AE, Boynton RE, Behn BG, Brown BWJI. Variation of the Human Menstrual Cycle Through Reproductive Life. Int J Fertil (1967) 12:77-126.

10. Byers M, Kuiper GGJM, Gustafsson JA, ParkSarge OK. Estrogen ReceptorBeta mRNA Expression in Rat Ovary: Down-Regulation by Gonadotropins. Mol Endocrinol (1997) 11:172-82. doi: 10.1210/mend.11.2.9887

11. Couse JF, Lindzey J, Grandien K, Gustafsson JA, Korach KS. Tissue Distribution and Quantitative Analysis of Estrogen Receptor-Alpha (ER endocrine diseases. In view of these considerations, a better understanding of the complex regulatory mechanisms that underlie ER actions is necessary to identify therapeutic approaches that could protect female ovarian health from estrogen, estrogen target tissue malignancies, and diseases associated with estrogen deficiency.

\section{AUTHOR CONTRIBUTIONS}

$\mathrm{KY}, \mathrm{X}-\mathrm{LX}$, and $\mathrm{Z}$-YH reviewed the literature, wrote the manuscript and designed the figures and tables. JL revised the draft. X-WF and S-LD made substantial contributions to the conception and design of the work, and provided input into manuscript content and composition. All authors contributed to the article and approved the submitted version.

\section{FUNDING}

This work was supported by National Nature Science Foundation Project of China (No. 32072722, 31101714 \& 31372307).

\section{ACKNOWLEDGMENTS}

We thank Wei Yan, Ph.D. and Ryan Chastain-Gross, Ph.D.(from Liwen Bianji, Edanz Group China www.liwenbianji.cn/ac), for editing the English text of a draft of this manuscript.

Alpha) and Estrogen Receptor-Beta (ER Beta) Messenger Ribonucleic Acid in the Wild-Type and ER Alpha-Knockout Mouse. Endocrinology (1997) 138:4613-21. doi: 10.1210/endo.138.11.5496

12. Kuiper GGJM, Carlsson B, Grandien K, Enmark E, Haggblad J, Nilsson S, et al. Comparison of the Ligand Binding Specificity and Transcript Tissue Distribution of Estrogen Receptors Alpha and Beta. Endocrinology (1997) 138:863-70. doi: 10.1210/endo.138.3.4979

13. Walter P, Green S, Greene G, Krust A, Bornert JM, Jeltsch JM, et al. Cloning of the Human Estrogen-Receptor Cdna. Proc Natl Acad Sci USA (1985) 82:7889-93. doi: 10.1073/pnas.82.23.7889

14. Mosselman S, Polman J, Dijkema R. ER Beta: Identification and Characterization of a Novel Human Estrogen Receptor. FEBS Lett (1996) 392:49-53. doi: 10.1016/0014-5793(96)00782-X

15. Pelletier G, El-Alfy M. Immunocytochemical Localization of Estrogen Receptors Alpha and Beta in the Human Reproductive Organs. J Clin Endocr Metab (2000) 85:4835-40. doi: 10.1210/jcem.85.12.7029

16. Yeh CR, Da J, Song W, Fazili A, Yeh S. Estrogen Receptors in Prostate Development and Cancer. Am J Clin Exp Urol (2014) 2:161-8.

17. Sar M, Welsch F. Differential Expression of Estrogen Receptor-Beta and Estrogen Receptor-Alpha in the Rat Ovary. Endocrinology (1999) 140:96371. doi: 10.1210 /endo.140.2.6533

18. Hiroi H, Inoue S, Watanabe T, Goto W, Orimo A, Momoeda M, et al. Differential Immunolocalization of Estrogen Receptor Alpha and Beta in Rat Ovary and Uterus. J Mol Endocrinol (1999) 22:37-44. doi: 10.1677/jme.0.0220037

19. Braidman IP, Hainey L, Batra G, Selby PL, Saunders PTK, Hoyland JA. Localization of Estrogen Receptor Beta Protein Expression in Adult Human Bone. J Bone Miner Res (2001) 16:214-20. doi: 10.1359/jbmr.2001.16.2.214

20. Royuela M, de Miguel MP, Bethencourt FR, Sanchez-Chapado M, Fraile B, Arenas MI, et al. Estrogen Receptors Alpha and Beta in the Normal, Hyperplastic and Carcinomatous Human Prostate. J Endocrinol (2001) 168:447-54. doi: 10.1677/joe.0.1680447 
21. Dotzlaw H, Leygue E, Watson PH, Murphy LC. Expression of Estrogen Receptor-Beta in Human Breast Tumors. J Clin Endocr Metab (1997) 82:2371-4. doi: $10.1210 /$ jcem.82.7.4212

22. Vladusic EA, Hornby AE, Guerra-Vladusic FK, Lupu R. Expression of Estrogen Receptor Beta Messenger RNA Variant in Breast Cancer. Cancer Res (1998) 58:210-4.

23. Dotzlaw H, Leygue E, Watson PH, Murphy LC. Estrogen Receptor-Beta Messenger RNA Expression in Human Breast Tumor Biopsies: Relationship to Steroid Receptor Status and Regulation by Progestins. Cancer Res (1999) 59:529-32.

24. Saunders PTK, Millar MR, Williams K, Macpherson S, Harkiss D, Anderson RA, et al. Differential Expression of Estrogen Receptor-Alpha and -Beta and Androgen Receptor in the Ovaries of Marmosets and Humans. Biol Reprod (2000) 63:1098-105. doi: 10.1095/biolreprod63.4.1098

25. Hillier SG, Anderson RA, Williams ARW, Tetsuka M. Expression of Oestrogen Receptor Alpha and Beta in Cultured Human Ovarian Surface Epithelial Cells. Mol Hum Reprod (1998) 4:811-5. doi: 10.1093/molehr/ 4.8.811

26. Scobie GA, Macpherson S, Millar MR, Groome NP, Romana PG, Saunders PTK. Human Oestrogen Receptors: Differential Expression of ERalpha and Beta and the Identification of ERbeta Variants. Steroids (2002) 67:985-92. doi: 10.1016/S0039-128X(02)00047-8

27. Maiti K, Paul JW, Read M, Chan EC, Riley SC, Nahar P. Smith, R. G-1Activated Membrane Estrogen Receptors Mediate Increased Contractility of the Human Myometrium. Endocrinology (2011) 152:2448-55. doi: 10.1210/ en.2010-0979

28. Zang LL, Zhang Q, Zhou Y, Zhao Y, Lu LL, Jiang Z, et al. Expression Pattern of G Protein-Coupled Estrogen Receptor 1 (GPER) in Human Cumulus Granulosa Cells (CGCs) of Patients With PCOS. Syst Biol Reprod Med (2016) 62:184-91. doi: 10.3109/19396368.2016.1164260

29. Enmark E, Pelto-Huikko M, Grandien K, Lagercrantz S, Lagercrantz J, Fried G, et al. Human Estrogen Receptor Beta-Gene Structure, Chromosomal Localization, and Expression Pattern. J Clin Endocr Metab (1997) 82:425865. doi: $10.1210 /$ jc. 82.12 .4258

30. Coppens MT, Deboever JG, Dhont MA, Serreyn RF, Vandekerckhove DA, Roels HJ. Topographical Distribution of Estrogen and Progesterone Receptors in the Human Endometrium and Fallopian-Tube - an Immunocytochemical Study. Histochemistry (1993) 99:127-31. doi: 10.1007/BF00571873

31. Amso NN, Crow J, Shaw RW. Comparative Immunohistochemical Study of Estrogen and Progesterone Receptors in the Fallopian-Tube and Uterus at Different Stages of the Menstrual-Cycle and the Menopause. Hum Reprod (1994) 9:1027-37. doi: 10.1093/oxfordjournals.humrep.a138628

32. Welsh TH, Zhuang LZ, Hsueh AJW. Estrogen Augmentation of Gonadotropin-Stimulated Progestin Biosynthesis in Cultured Rat Granulosa-Cells. Endocrinology (1983) 112:1916-24. doi: 10.1210/endo112-6-1916

33. Tang ZR, Zhang R, Lian ZX, Deng SL, Yu K. Estrogen-Receptor Expression and Function in Female Reproductive Disease. Cells (2019) 8:1123. doi: 10.3390/cells 8101123

34. Deroo BJ, Korach KS. Estrogen Receptors and Human Disease. J Clin Invest (2006) 116:561-70. doi: 10.1172/JCI27987

35. Mangelsdorf DJ, Thummel C, Beato M, Herrlich P, Schutz G, Umesono K, et al. The Nuclear Receptor Superfamily - The 2nd Decade. Cell (1995) 83:835-9. doi: 10.1016/0092-8674(95)90199-X

36. Chakraborty S, Willett H, Biswas PK. Insight Into Estrogen Receptor BetaBeta and Alpha-Beta Homo- and Heterodimerization: A Combined Molecular Dynamics and Sequence Analysis Study. Biophys Chem (2012) 170:42-50. doi: 10.1016/j.bpc.2012.09.002

37. Bourguet W, Germain P, Gronemeyer H. Nuclear Receptor Ligand-Binding Domains Three-Dimensional Structures, Molecular Interactions and Pharmacological Implications. Trends Pharmacol Sci (2000) 21:381-8. doi: 10.1016/S0165-6147(00)01548-0

38. Klinge CM. Estrogen Receptor Interaction With Estrogen Response Elements. Nucleic Acids Res (2001) 29:2905-19. doi: 10.1093/nar/29.14.2905

39. Cheung E, Acevedo ML, Cole PA, Kraus WL. Altered Pharmacology and Distinct Coactivator Usage for Estrogen Receptor-Dependent Transcription Through Activating Protein-1. Proc Natl Acad Sci USA (2005) 102:559-64. doi: 10.1073/pnas.0407113102
40. Bjornstrom L, Sjoberg M. Mutations in the Estrogen Receptor DNA-Binding Domain Discriminate Between the Classical Mechanism of Action and Cross-Talk With Stat5b and Activating Protein 1 (AP-1). J Biol Chem (2002) 277:48479-83. doi: 10.1074/jbc.C200570200

41. Kushner PJ, Agard DA, Greene GL, Scanlan TS, Shiau AK, Uht RM, et al. Estrogen Receptor Pathways to AP-1. J Steroid Biochem Mol Biol (2000) 74:311-7. doi: 10.1016/S0960-0760(00)00108-4

42. Marino M, Ascenzi P, Acconcia F. S-Palmitoylation Modulates Estrogen Receptor Alpha Localization and Functions. Steroids (2006) 71:298-303. doi: 10.1016/j.steroids.2005.09.011

43. Kelly MJ, Levin ER. Rapid Actions of Plasma Membrane Estrogen Receptors. Trends Endocrinol Metab (2001) 12:152-6. doi: 10.1016/S1043-2760(01) 00377-0

44. Segars JH, Driggers PH. Estrogen Action and Cytoplasmic Signaling Cascades. Part I: Membrane-Associated Signaling Complexes. Trends Endocrinol Metab (2002) 13:349-54. doi: 10.1016/S1043-2760(02)00633-1

45. Prossnitz ER, Barton M. Estrogen Biology: New Insights Into GPER Function and Clinical Opportunities. Mol Cell Endocrinol (2014) 389:7183. doi: $10.1016 /$ j.mce.2014.02.002

46. Smith CL. Cross-Talk Between Peptide Growth Factor and Estrogen Receptor Signaling Pathways. Biol Reprod (1998) 58:627-32. doi: 10.1095/ biolreprod58.3.627

47. Clark S, Rainville J, Zhao X, Katzenellenbogen BS, Pfaff D, Vasudevan N. Estrogen Receptor-Mediated Transcription Involves the Activation of Multiple Kinase Pathways in Neuroblastoma Cells. J Steroid Biochem Mol Biol (2014) 139:45-53. doi: 10.1016/j.jsbmb.2013.09.010

48. Couse JF, Yates MM, Walker VR, Korach KS. Characterization of the Hypothalamic-Pituitary-Gonadal Axis in Estrogen Receptor (ER) Null Mice Reveals Hypergonadism and Endocrine Sex Reversal in Females Lacking ER Alpha But Not ER Beta. Mol Endocrinol (2003) 17:1039-53. doi: 10.1210/me.2002-0398

49. Lee S, Kang DW, Hudgins-Spivey S, Krust A, Lee EY, Koo Y, et al. ThecaSpecific Estrogen Receptor-Alpha Knockout Mice Lose Fertility Prematurely. Endocrinology (2009) 150:3855-62. doi: 10.1210/en.2008-1774

50. Couse JF, Hewitt SC, Bunch DO, Sar M, Walker VR, Davis BJ, et al. Postnatal Sex Reversal of the Ovaries in Mice Lacking Estrogen Receptors Alpha and Beta. Science (1999) 286:2328-31. doi: 10.1126/science.286.5448.2328

51. Sinkevicius KW, Burdette JE, Woloszyn K, Hewitt SC, Hamilton K, Sugg SL, et al. An Estrogen Receptor-Alpha Knock-in Mutation Provides Evidence of Ligand-Independent Signaling and Allows Modulation of Ligand-Induced Pathways In Vivo. Endocrinology (2008) 149:2970-9. doi: 10.1210/en.20071526

52. Rulli SB, Huhtaniemi I. What Have Gonadotrophin Overexpressing Transgenic Mice Taught Us About Gonadal Function? Reproduction (2005) 130:283-91. doi: 10.1530/rep.1.00661

53. Couse JF, Yates MM, Sanford R, Nyska A, Nilson JH, Korach KS. Formation of Cystic Ovarian Follicles Associated With Elevated Luteinizing Hormone Requires Estrogen Receptor-Beta. Endocrinology (2004) 145:4693-702. doi: 10.1210/en.2004-0548

54. Krege JH, Hodgin JB, Couse JF, Enmark E, Warner M, Mahler JF, et al. Generation and Reproductive Phenotypes of Mice Lacking Estrogen Receptor Beta. Proc Natl Acad Sci USA (1998) 95:15677-82. doi: 10.1073/ pnas.95.26.15677

55. Dupont S, Krust A, Gansmuller A, Dierich A, Chambon P, Mark M. Effect of Single and Compound Knockouts of Estrogen Receptors Alpha (ER Alpha) and Beta (ER Beta) on Mouse Reproductive Phenotypes. Development (2000) 127:4277-91. doi: 10.1242/dev.127.19.4277

56. Couse JF, Yates MM, Deroo BJ, Korach KS. Estrogen Receptor-Beta Is Critical to Granulosa Cell Differentiation and the Ovulatory Response to Gonadotropins. Endocrinology (2005) 146:3247-62. doi: 10.1210/en.20050213

57. Lubahn DB, Moyer JS, Golding TS, Couse JF, Korach KS, Smithies O. Alteration of Reproductive Function But Not Prenatal Sexual Development After Insertional Disruption of the Mouse Estrogen-Receptor Gene. P Natl Acad Sci USA (1993) 90:11162-6. doi: 10.1073/pnas.90.23.11162

58. Couse JF, Korach KS. Estrogen Receptor Null Mice: What Have We Learned and Where Will They Lead Us? (Vol 20, Pg 358, 1999). Endocrine Rev (1999) 20:459-9. doi: 10.1210/edrv.20.3.0370 
59. Maeda K, Adachi S, Inoue K, Ohkura S, Tsukamura H. Metastin/kisspeptin and Control of Estrous Cycle in Rats. Rev Endocr Metab Disord (2007) 8:219. doi: 10.1007/s11154-007-9032-6

60. Wintermantel TM, Campbell RE, Porteous R, Bock D, Grone HJ, Todman MG, et al. Definition of Estrogen Receptor Pathway Critical for Estrogen Positive Feedback to Gonadotropin-Releasing Hormone Neurons and Fertility. Neuron (2006) 52:271-80. doi: 10.1016/j.neuron.2006.07.023

61. Cheong RY, Porteous R, Chambon P, Abrahám I, Herbison AE. Effects of Neuron-Specific Estrogen Receptor (ER) $\alpha$ and $\operatorname{Er} \beta$ Deletion on the Acute Estrogen Negative Feedback Mechanism in Adult Female Mice. Endocrinology (2014) 155:1418-27. doi: 10.1210/en.2013-1943

62. Antal MC, Krust A, Chambon P, Mark M. Sterility and Absence of Histopathological Defects in Nonreproductive Organs of a Mouse ERbetaNull Mutant. Proc Natl Acad Sci USA (2008) 105:2433-8. doi: 10.1073/ pnas. 0712029105

63. Mitchner NA, Garlick C, Ben-Jonathan N. Cellular Distribution and Gene Regulation of Estrogen Receptors Alpha and Beta in the Rat Pituitary Gland. Endocrinology (1998) 139:3976-83. doi: 10.1210/endo.139.9.6181

64. Gieske MC, Kim HJ, Legan SJ, Koo Y, Krust A, Chambon P, et al. Pituitary Gonadotroph Estrogen Receptor-Alpha is Necessary for Fertility in Females. Endocrinology (2008) 149:20-7. doi: 10.1210/en.2007-1084

65. Singh SP, Wolfe A, Ng Y, DiVall SA, Buggs C, Levine JE, et al. Impaired Estrogen Feedback and Infertility in Female Mice With Pituitary-Specific Deletion of Estrogen Receptor Alpha (Esr1). Biol Reprod (2009) 81:488-96. doi: 10.1095/biolreprod.108.075259

66. Arao Y, Hamilton KJ, Wu SP, Tsai MJ, DeMayo FJ, Korach KS. Dysregulation of Hypothalamic-Pituitary Estrogen Receptor AlphaMediated Signaling Causes Episodic LH Secretion and Cystic Ovary. FASEB J (2019) 33:7375-86. doi: 10.1096/fj.201802653RR

67. Wang C, Prossnitz ER, Roy SK. Expression of G Protein-Coupled Receptor 30 in the Hamster Ovary: Differential Regulation by Gonadotropins and Steroid Hormones. Endocrinology (2007) 148:4853-64. doi: 10.1210/ en.2007-0727

68. Wang C, Prossnitz ER, Roy SKJE. G Protein-Coupled Receptor 30 Expression is Required for Estrogen Stimulation of Primordial Follicle Formation in the Hamster Ovary. Endocrinology (2008) 149:4452-61. doi: 10.1210/en.2008-0441

69. Otto C, Fuchs I, Kauselmann G, Kern H, Zevnik B, Andreasen P, et al. GPR30 Does Not Mediate Estrogenic Responses in Reproductive Organs in Mice. Biol Reprod (2009) 80:34-41. doi: 10.1095/biolreprod.108.071175

70. Novaira HJ, Negron AL, Graceli JB, Capellino S, Schoeffield A, Hoffman GE, et al. Impairments in the Reproductive Axis of Female Mice Lacking Estrogen Receptor $\beta$ in GnRH Neurons. Am J Physiol Endocrinol Metab (2018) 315:E1019-e33. doi: 10.1152/ajpendo.00173.2018

71. Hu M, Li J, Zhang Y, Li X, Brannstrom M, Shao LR, et al. Endometrial Progesterone Receptor Isoforms in Women With Polycystic Ovary Syndrome. Am J Transl Res (2018) 10:2696-705.

72. Chang J, Azziz R, Legro R, Dewailly D, Franks S, Tarlatzis BC, et al. Revised 2003 Consensus on Diagnostic Criteria and Long-Term Health Risks Related to Polycystic Ovary Syndrome. Fertil Steril (2004) 81:19-25. doi: 10.1016/ j.fertnstert.2003.10.004

73. Carmina E, Lobo RA. Polycystic Ovaries in Hirsute Women With Normal Menses. Am J Med (2001) 111:602-6. doi: 10.1016/S0002-9343(01)00979-2

74. Kowalczyk K, Franik G, Kowalczyk D, Pluta D, Blukacz L, Madej P. Thyroid Disorders in Polycystic Ovary Syndrome. Eur Rev Med Pharmacol Sci (2017) 21:346-60.

75. Artimani T, Saidijam M, Aflatoonian R, Amiri I, Ashrafi M, Shabab N, et al. Estrogen and Progesterone Receptor Subtype Expression in Granulosa Cells From Women With Polycystic Ovary Syndrome. Gynecol Endocrinol (2015) 31:379-83. doi: 10.3109/09513590.2014.1001733

76. Qiao GY, Dong BW, Zhu CJ, Yan CY, Chen BL. Deregulation of WNT2/ FZD3/beta-Catenin Pathway Compromises the Estrogen Synthesis in Cumulus Cells From Patients With Polycystic Ovary Syndrome. Biochem Biophys Res Commun (2017) 493:847-54. doi: 10.1016/j.bbrc.2017.07.057

77. Jakimiuk AJ, Weitsman SR, Yen H-W, Bogusiewicz M, Magoffin DA. Estrogen Receptor $\alpha$ and $\beta$ Expression in Theca and Granulosa Cells From Women With Polycystic Ovary Syndrome. J Clin Endocrinol Metab (2002) 87:5532-8. doi: 10.1210/jc.2002-020323
78. Ferreira SR, Motta AB. Uterine Function: From Normal to Polycystic Ovarian Syndrome Alterations. Curr Med Chem (2018) 25:1792-804. doi: 10.2174/0929867325666171205144119

79. Piltonen TT. Polycystic Ovary Syndrome: Endometrial Markers. Best Pract Res Clin Obstet Gynaecol (2016) 37:66-79. doi: 10.1016/j.bpobgyn. 2016.03.008

80. Gregory CW, Wilson EM, Apparao K, Lininger RA, Meyer WR, Kowalik A, et al. Steroid Receptor Coactivator Expression Throughout the Menstrual Cycle in Normal and Abnormal Endometrium. J Clin Endocrinol Metab (2002) 87:2960-6. doi: 10.1210/jcem.87.6.8572

81. Kim JY, Song H, Kim H, Kang HJ, Jun JH, Hong SR, et al. Transcriptional Profiling With a Pathway-Oriented Analysis Identifies Dysregulated Molecular Phenotypes in the Endometrium of Patients With Polycystic Ovary Syndrome. J Clin Endocrinol Metab (2009) 94:1416-26. doi: 10.1210/ jc.2008-1612

82. Quezada S, Avellaira C, Johnson MC, Gabler F, Fuentes A, Vega M. Evaluation of Steroid Receptors, Coregulators, and Molecules Associated With Uterine Receptivity in Secretory Endometria From Untreated Women With Polycystic Ovary Syndrome. Fertil Steril (2006) 85:1017-26. doi: 10.1016/j.fertnstert.2005.09.053

83. Villavicencio A, Bacallao K, Avellaira C, Gabler F, Fuentes A, Vega M. Androgen and Estrogen Receptors and Co-Regulators Levels in Endometria From Patients With Polycystic Ovarian Syndrome With and Without Endometrial Hyperplasia. Gynecol Oncol (2006) 103:307-14. doi: 10.1016/ j.ygyno.2006.03.029

84. Maliqueo M, Clementi M, Gabler F, Johnson MC, Palomino A, SirPetermann T, et al. Expression of Steroid Receptors and Proteins Related to Apoptosis in Endometria of Women With Polycystic Ovary Syndrome. Fertil Steril (2003) 80:812-9. doi: 10.1016/S0015-0282(03)00987-7

85. Hulchiy M, Nybacka $\AA$, Sahlin L, Hirschberg AL. Endometrial Expression of Estrogen Receptors and the Androgen Receptor in Women With Polycystic Ovary Syndrome: A Lifestyle Intervention Study. J Clin Endocrinol Metab (2016) 101:561-71. doi: 10.1210/jc.2015-3803

86. Gellersen B, Brosens JJ. Cyclic Decidualization of the Human Endometrium in Reproductive Health and Failure. Endocrine Rev (2014) 35:851-905. doi: 10.1210/er.2014-1045

87. Hu M, Zhang Y, Egecioglu E, Li X, Shao LR, Billig H. Uterine Glycolytic Enzyme Expression is Affected by Knockout of Different Estrogen Receptor Subtypes. Biomed Rep (2019) 11:135-44. doi: 10.3892/br.2019.1234

88. Imamov O, Shim GJ, Warner M, Gustafsson JA. Estrogen Receptor Beta in Health and Disease. Biol Reprod (2005) 73:866-71. doi: 10.1095/ biolreprod.105.043497

89. Silva F, Sóter M, Sales M, Candido A, Reis F, Silva I, et al. Estrogen Receptor olpha Gene (ESR1) PvuII and XbaI Polymorphisms Are Associated to Metabolic and Proinflammatory Factors in Polycystic Ovary Syndrome. Gene (2015) 560:44-9. doi: 10.1016/j.gene.2015.01.037

90. Liaqat I, Jahan N, Krikun G, Taylor HS. Genetic Polymorphisms in Pakistani Women With Polycystic Ovary Syndrome. Reprod Sci (Thousand Oaks Calif) (2015) 22:347-57. doi: 10.1177/1933719114542015

91. Jiao X, Chen W, Zhang J, Wang W, Song J, Chen D, et al. Variant Alleles of the ESR1, PPARG, HMGA2, and MTHFR Genes Are Associated With Polycystic Ovary Syndrome Risk in a Chinese Population: A Case-Control Study. Front Endocrinol (Lausanne) (2018) 9:504. doi: 10.3389/fendo. 2018.00504

92. Kim JJ, Choi YM, Choung SH, Yoon SH, Lee GH, Moon SY. Estrogen Receptor Beta Gene+ 1730 G/A Polymorphism in Women With Polycystic Ovary Syndrome. Fertil Steril (2010) 93:1942-7. doi: 10.1016/j.fertnstert. 2008.12.040

93. Levin JH, Carmina E, Lobo RA. Is the Inappropriate GonadotropinSecretion of Patients With Polycystic-Ovary-Syndrome Similar to That of Patients With Adult-Onset Congenital Adrenal-Hyperplasia. Fertil Steril (1991) 56:635-40. doi: 10.1016/S0015-0282(16)54592-0

94. Mahesh VB, Brann DW. Regulation of the Preovulatory Gonadotropin Surge by Endogenous Steroids. Steroids (1998) 63:616-29. doi: 10.1016/ S0039-128X(98)00075-0

95. Scully KM, Gleiberman AS, Lindzey J, Lubahn DB, Korach KS, Rosenfeld MG. Role of Estrogen Receptor-Alpha in the Anterior Pituitary Gland. Mol Endocrinol (1997) 11:674-81. doi: 10.1210/mend.11.6.0019 
96. Zhou S, Wen S, Sheng Y, Yang M, Shen X, Chen Y, et al. Association of Estrogen Receptor Genes Polymorphisms With Polycystic Ovary Syndrome: A Systematic Review and Meta-Analysis Based on Observational Studies. Front Endocrinol (Lausanne) (2021) 12:726184. doi: 10.3389/fendo. 2021.726184

97. Gonzalez F. Adrenal Involvement in Polycystic Ovary Syndrome. Semin Reprod Endocrinol (1997) 15:137-57. doi: 10.1055/s-2007-1016296

98. Yildiz BO, Azziz R. The Adrenal and Polycystic Ovary Syndrome. Rev Endocr Metab Dis (2007) 8:331-42. doi: 10.1007/s11154-007-9054-0

99. Greenblatt RB, Mahesh VB. The Androgenic Polycystic Ovary. Am J Obstet Gynecol (1976) 125:712-26. doi: 10.1016/0002-9378(76)90801-2

100. Fruzzetti F, De Lorenzo D, Ricci C, Teti G. Ovarian Influence on Adrenal Androgen Secretion in Polycystic Ovary Syndrome. Fertil Steril (1995) 63:734-41. doi: 10.1016/S0015-0282(16)57474-3

101. Carmina E, Gonzalez F, Chang L, Lobo RA. Reassessment of Adrenal Androgen Secretion in Women With Polycystic Ovary Syndrome. Obstet Gynecol (1995) 85:971-6. doi: 10.1016/0029-7844(95)00065-Y

102. Pang Y, Dong J, Thomas P. Estrogen Signaling Characteristics of Atlantic Croaker G Protein-Coupled Receptor 30 (GPR30) and Evidence It Is Involved in Maintenance of Oocyte Meiotic Arrest. Endocrinology (2008) 149:3410-26. doi: 10.1210/en.2007-1663

103. Majumder S, Das S, Moulik SR, Mallick B, Pal P, Mukherjee D. G-Protein Coupled Estrogen Receptor (GPER) Inhibits Final Oocyte Maturation in Common Carp, Cyprinus Carpio. Gen Comp Endocr (2015) 211:28-38. doi: 10.1016/j.ygcen.2014.11.011

104. Peyton C, Thomas P. Involvement of Epidermal Growth Factor Receptor Signaling in Estrogen Inhibition of Oocyte Maturation Mediated Through the G Protein-Coupled Estrogen Receptor (Gper) in Zebrafish (Danio Rerio). Biol Reprod (2011) 85:42-50. doi: 10.1095/biolreprod.110.088765

105. Ferlay J, Soerjomataram I, Dikshit R, Eser S, Mathers C, Rebelo M, et al. Cancer Incidence and Mortality Worldwide: Sources, Methods and Major Patterns in GLOBOCAN 2012. Int J Cancer (2015) 136:E359-86. doi: $10.1002 / \mathrm{ijc} .29210$

106. Lheureux S, Gourley C, Vergote I, Oza AM. Epithelial Ovarian Cancer. Lancet (2019) 393:1240-53. doi: 10.1016/S0140-6736(18)32552-2

107. Englert-Golon M, Andrusiewicz M, Zbikowska A, Chmielewska M, Sajdak S, Kotwicka M. Altered Expression of ESR1, ESR2, PELP1 and C-SRC Genes Is Associated With Ovarian Cancer Manifestation. Int J Mol Sci (2021) 22:6216. doi: 10.3390/ijms22126216

108. Li SR, Li Y, Wen ZF, Kong FJ, Guan XL, Liu WH. microRNA-206 Overexpression Inhibits Cellular Proliferation and Invasion of Estrogen Receptor Alpha-Positive Ovarian Cancer Cells. Mol Med Rep (2014) 9:1703-8. doi: 10.3892/mmr.2014.2021

109. Qiu JJ, Ye LC, Ding JX, Feng WW, Jin HY, Zhang Y, et al. Expression and Clinical Significance of Estrogen-Regulated Long Non-Coding RNAs in Estrogen Receptor Alpha-Positive Ovarian Cancer Progression. Oncol Rep (2014) 31:1613-22. doi: 10.3892/or.2014.3000

110. O’Donnell AJ, Macleod KG, Burns DJ, Smyth JF, Langdon SP. Estrogen Receptor-Alpha Mediates Gene Expression Changes and Growth Response in Ovarian Cancer Cells Exposed to Estrogen. Endocr Relat Cancer (2005) 12:851-66. doi: 10.1677/erc.1.01039

111. Chan KKL, Leung THY, Chan DW, Wei N, Lau GTY, Liu SS, et al. Targeting Estrogen Receptor Subtypes (ER Alpha and ER Beta) With Selective ER Modulators in Ovarian Cancer. J Endocrinol (2014) 221:325-36. doi: 10.1530/JOE-13-0500

112. Treeck O, Pfeiler G, Mitter D, Lattrich C, Piendl G, Ortmann O. Estrogen Receptor Beta 1 Exerts Antitumoral Effects on SK-OV-3 Ovarian Cancer Cells. J Endocrinol (2007) 193:421-33. doi: 10.1677/JOE-07-0087

113. Bossard C, Busson M, Vindrieux D, Gaudin F, Machelon R, Brigitte M, et al. Potential Role of Estrogen Receptor Beta as a Tumor Suppressor of Epithelial Ovarian Cancer. PloS One (2012) 7:e44787. doi: 10.1371/journal. pone. 0044787

114. Moore JT, McKee DD, Slentz-Kesler K, Moore LB, Jones SA, Horne EL, et al. Cloning and Characterization of Human Estrogen Receptor Beta Isoforms. Biochem Bioph Res Co (1998) 247:75-8. doi: 10.1006/bbrc.1998.8738

115. Ciucci A, Zannoni GF, Travaglia D, Petrillo M, Scambia G, Gallo D. Prognostic Significance of the Estrogen Receptor Beta (ER Beta) Isoforms
ER Beta 1, ER Beta 2, and ER Beta 5 in Advanced Serous Ovarian Cancer. Gynecol Oncol (2014) 132:351-9. doi: 10.1016/j.ygyno.2013.12.027

116. Kolkova Z, Casslen V, Henic E, Ahmadi S, Ehinger A, Jirstrom K, et al. The G Protein-Coupled Estrogen Receptor 1 (GPER/GPR30) Does Not Predict Survival in Patients With Ovarian Cancer. J Ovarian Res (2012) 5:9. doi: 10.1186/1757-2215-5-9

117. Ignatov T, Modl S, Thulig M, Weissenborn C, Treeck O, Ortmann O, et al. GPER-1 Acts as a Tumor Suppressor in Ovarian Cancer. J Ovarian Res (2013) 6:51. doi: 10.1186/1757-2215-6-51

118. Yan Y, Jiang XL, Zhao Y, Wen HX, Liu GY. Role of GPER on Proliferation, Migration and Invasion in Ligand-Independent Manner in Human Ovarian Cancer Cell Line SKOV3. Cell Biochem Funct (2015) 33:552-9. doi: 10.1002/ cbf.3154

119. Albanito L, Madeo A, Lappano R, Vivacqua A, Rago V, Carpino A, et al. G Protein-Coupled Receptor 30 (GPR30) Mediates Gene Expression Changes and Growth Response to 17 Beta-Estradiol and Selective GPR30 Ligand G-1 in Ovarian Cancer Cells. Cancer Res (2007) 67:1859-66. doi: 10.1158/00085472.CAN-06-2909

120. Miller SM, Green ML, Depinto JV, Hornbuckle KC. Results From the Lake Michigan Mass Balance Study: Concentrations and Fluxes of Atmospheric Polychlorinated Biphenyls and Trans-Nonachlor. Environ Sci Technol (2001) 35:278-85. doi: 10.1021/es991463b

121. Solomon KR, Giesy JP, LaPoint TW, Giddings JM, Richards RP. Ecological Risk Assessment of Atrazine in North American Surface Waters. Environ Toxicol Chem (2013) 32:10-1. doi: 10.1002/etc.2050

122. Albanito L, Lappano R, Madeo A, Chimento A, Prossnitz ER, Cappello AR, et al. G-Protein-Coupled Receptor 30 and Estrogen Receptor-Alpha Are Involved in the Proliferative Effects Induced by Atrazine in Ovarian Cancer Cells (Retracted Article. See Vol. 122, Pg. A42, 2014). Environ Health Perspect (2008) 116:1648-55. doi: 10.1289/ehp.11297

123. Coulam CB, Adamson SC, Annegers JF. Incidence of Premature Ovarian Failure. Obstet Gynecol (1986) 67:604-6.

124. Meskhi A, Seif MW. Premature Ovarian Failure. Curr Opin Obstet Gyn (2006) 18:418-26. doi: 10.1097/01.gco.0000233937.36554.d3

125. Welt CK. Primary Ovarian Insufficiency: A More Accurate Term for Premature Ovarian Failure. Clin Endocrinol (2008) 68:499-509. doi: 10.1111/j.1365-2265.2007.03073.x

126. Goswami D, Conway GS. Premature Ovarian Failure. Hum Reprod Update (2005) 11:391-410. doi: 10.1093/humupd/dmi012

127. Bretherick KL, Hanna CW, Currie LM, Fluker MR, Hammond GL, Robinson WP. Estrogen Receptor Alpha Gene Polymorphisms Are Associated With Idiopathic Premature Ovarian Failure. Fertil Steril (2008) 89:318-24. doi: 10.1016/j.fertnstert.2007.03.008

128. M'Rabet N, Moffat R, Helbling S, Kaech A, Zhang H, de Geyter C. The CCAllele of the PvuII Polymorphic Variant in Intron 1 of the Alpha-Estrogen Receptor Gene is Significantly More Prevalent Among Infertile Women at Risk of Premature Ovarian Aging. Fertil Steril (2012) 98:965-72.e965. doi: 10.1016/j.fertnstert.2012.05.048

129. Cordts EB, Santos AA, Peluso C, Bianco B, Barbosa CP, Christofolini DM. Risk of Premature Ovarian Failure Is Associated to the PvuII Polymorphism at Estrogen Receptor Gene ESR1. J Assisted Reprod Genet (2012) 29:1421-5. doi: 10.1007/s10815-012-9884-x

130. Yang JJ, Cho LY, Lim YJ, Ko KP, Lee KS, Kim H, et al. Estrogen Receptor-1 Genetic Polymorphisms for the Risk of Premature Ovarian Failure and Early Menopause. J Womens Health (2010) 19:297-304. doi: 10.1089/ jwh.2008.1317

131. Yoon SH, Choi YM, Hong MA, Lee GH, Kim JJ, Im HJ, et al. Estrogen Receptor Alpha Gene Polymorphisms in Patients With Idiopathic Premature Ovarian Failure. Hum Reprod (2010) 25:283-7. doi: 10.1093/humrep/dep375

132. Martinkovich S, Shah D, Planey SL, Arnott J. Selective Estrogen Receptor Modulators: Tissue Specificity and Clinical Utility. Clin Interv Aging (2014) 9:1437. doi: 10.2147/CIA.S66690

133. Metivier R, Penot G, Flouriot G, Pakdel F. Synergism Between ER Alpha Transactivation Function 1 (AF-1) and AF-2 Mediated by Steroid Receptor Coactivator Protein-1: Requirement for the AF-1 Alpha-Helical Core and for a Direct Interaction Between the $\mathrm{N}$ - and C-Terminal Domains. Mol Endocrinol (2001) 15:1953-70. doi: 10.1210/mend.15.11.0727 
134. Kato S, Endoh H, Masuhiro Y, Kitamoto T, Uchiyama S, Sasaki H, et al. Activation of the Estrogen-Receptor Through Phosphorylation by MitogenActivated Protein-Kinase. Science (1995) 270:1491-4. doi: 10.1126/ science.270.5241.1491

135. Kumar V, Green S, Stack G, Berry M, Jin JR, Chambon P. Functional Domains of the Human Estrogen-Receptor. Cell (1987) 51:941-51. doi: 10.1016/0092-8674(87)90581-2

136. Berry M, Metzger D, Chambon P. Role of the 2 Activating Domains of the Estrogen-Receptor in the Cell-Type and Promoter-Context Dependent Agonistic Activity of the Antiestrogen 4-Hydroxytamoxifen. EMBO J (1990) 9:2811-8. doi: 10.1002/j.1460-2075.1990.tb07469.x

137. Michalides R, Griekspoor A, Balkenende A, Verwoerd D, Janssen L, Jalink K, et al. Tamoxifen Resistance by a Conformational Arrest of the Estrogen Receptor Alpha After PKA Activation in Breast Cancer. Cancer Cell (2004) 5:597-605. doi: 10.1016/j.ccr.2004.05.016

138. Webb P, Nguyen P, Valentine C, Lopez GN, Kwok GR, McInerney E, et al. The Estrogen Receptor Enhances AP-1 Activity by Two Distinct Mechanisms With Different Requirements for Receptor Transactivation Functions. Mol Endocrinol (1999) 13:1672-85. doi: 10.1210/mend. 13.10 .0357

139. Zwart W, de Leeuw R, Rondaij M, Neefjes J, Mancini MA, Michalides R. The Hinge Region of the Human Estrogen Receptor Determines Functional Synergy Between AF-1 and AF-2 in the Quantitative Response to Estradiol and Tamoxifen. J Cell Sci (2010) 123:1253-61. doi: 10.1242/jcs.061135

140. Clark JH, Markaverich BM. The Agonistic-Antagonistic Properties of Clomiphene - A Review. Pharmacol Therapeut (1981) 15:467-519. doi: 10.1016/0163-7258(81)90055-3

141. Medicine, P.C.o.t.A.S.f.R. Use of Clomiphene Citrate in Women. Fertil Steril (2003) 80:1302-8. doi: 10.1016/S0015-0282(03)01184-1

142. Mikkelson TJ, Kroboth PD, Cameron WJ, Dittert LW, Chungi V, Manberg PJ. Single-Dose Pharmacokinetics of Clomiphene Citrate in Normal Volunteers. Fertil Steril (1986) 46:392-6. doi: 10.1016/S0015-0282(16)49574-9

143. Kettel LM, Roseff SJ, Berga SL, Mortola JF, Yen SSC. HypothalamicPituitary-Ovarian Response to Clomiphene Citrate in Women With Polycystic-Ovary-Syndrome. Fertil Steril (1993) 59:532-8. doi: 10.1016/ S0015-0282(16)55795-1

144. Sir T, Alba F, Devoto L, Rossmanith W. Clomiphene Citrate and Lh Pulsatility in Pco Syndrome. Horm Metab Res (1989) 21:583-3. doi: 10.1055/s-2007-1009293

145. Bhagavath B, Carson SA. Ovulation Induction in Women With Polycystic Ovary Syndrome: An Update. Am J Obstet Gynecol (2012) 206:195-8. doi: 10.1016/j.ajog.2011.06.007

146. Gadalla MA, Huang S, Wang R, Norman RJ, Abdullah SA, El Saman AM, et al. Effect of Clomiphene Citrate on Endometrial Thickness, Ovulation, Pregnancy and Live Birth in Anovulatory Women: Systematic Review and Meta-Analysis. Ultrasound Obst Gyn (2018) 51:64-76. doi: 10.1002/ uog. 18933

147. Legro RS, Barnhart HX, Schlaff WD, Carr BR, Diamond MP, Carson SA, et al. Clomiphene, Metformin, or Both for Infertility in the Polycystic Ovary Syndrome. N Engl J Med (2007) 356:551-66. doi: 10.1056/NEJMoa063971

148. Casper RF, Mitwally MFM. A Historical Perspective of Aromatase Inhibitors for Ovulation Induction. Fertil Steril (2012) 98:1352-5. doi: 10.1016/ j.fertnstert.2012.10.008

149. Mitwally MFM, Casper RF. Use of an Aromatase Inhibitor for Induction of Ovulation in Patients With an Inadequate Response to Clomiphene Citrate. Fertil Steril (2001) 75:305-9. doi: 10.1016/S0015-0282(00)01705-2

150. Walker G, MacLeod K, Williams AR, Cameron DA, Smyth JF, Langdon SP. Estrogen-Regulated Gene Expression Predicts Response to Endocrine Therapy in Patients With Ovarian Cancer. Gynecol Oncol (2007) 106:4618. doi: 10.1016/j.ygyno.2007.05.009

151. Bowman A, Gabra H, Langdon SP, Lessells A, Stewart M, Young A, et al. CA125 Response Is Associated With Estrogen Receptor Expression in a Phase II Trial of Letrozole in Ovarian Cancer: Identification of an EndocrineSensitive Subgroup. Clin Cancer Res (2002) 8:2233-9.
152. Legro RS, Brzyski RG, Diamond MP, Coutifaris C, Schlaff WD, Casson P, et al. Letrozole Versus Clomiphene for Infertility in the Polycystic Ovary Syndrome. N Engl J Med (2014) 371:119-29. doi: 10.1056/NEJMoa 1313517

153. Bruni V, Dei M, Pontello V, Vangelisti P. The Management of Polycystic Ovary Syndrome. Ann N Y Acad Sci (2003) 997:307-21. doi: 10.1196/ annals.1290.034

154. Yildiz BO. Approach to the Patient: Contraception in Women With Polycystic Ovary Syndrome. J Clin Endocrinol Metab (2015) 100:794-802. doi: 10.1210/jc.2014-3196

155. Kahn JA, Gordon CM. Polycystic Ovary Syndrome. Adolesc Med (Philadelphia $\mathrm{Pa}$ ) (1999) 10:321-36.

156. Yildiz BO. Assessment, Diagnosis and Treatment of a Patient With Hirsutism. Nat Clin Practice Endocrinol Metab (2008) 4:294-300. doi: 10.1038/ncpendmet0789

157. Morin-Papunen L, Vauhkonen I, Koivunen R, Ruokonen A, Martikainen H, Tapanainen JS. Metformin Versus Ethinyl Estradiol-Cyproterone Acetate in the Treatment of Nonobese Women With Polycystic Ovary Syndrome: A Randomized Study. J Clin Endocrinol Metab (2003) 88:148-56. doi: 10.1210/ jc.2002-020997

158. Yang YM, Choi EJ. Efficacy and Safety of Metformin or Oral Contraceptives, or Both in Polycystic Ovary Syndrome. Ther Clin Risk Manage (2015) 11:1345-53. doi: 10.2147/TCRM.S89737

159. Wiegratz I, Kuhl H. Long-Cycle Treatment With Oral Contraceptives. Drugs (2004) 64:2447-62. doi: 10.2165/00003495-200464210-00006

160. Group ECW. Noncontraceptive Health Benefits of Combined Oral Contraception. Hum Reprod Update (2005) 11:513-25. doi: 10.1093/ humupd/dmi019

161. Prossnitz ER, Barton M. The G-Protein-Coupled Estrogen Receptor GPER in Health and Disease. Nat Rev Endocrinol (2011) 7:715-26. doi: 10.1038/ nrendo.2011.122

162. Yasar P, Ayaz G, User SD, Gupur G, Muyan M. Molecular Mechanism of Estrogen-Estrogen Receptor Signaling. Reprod Med Biol (2017) 16:4-20. doi: $10.1002 / \mathrm{rmb} 2.12006$

163. Le Romancer M, Poulard C, Cohen P, Sentis S, Renoir J-M, Corbo L. Cracking the Estrogen Receptor's Posttranslational Code in Breast Tumors. Endocrine Rev (2011) 32:597-622. doi: 10.1210/er.2010-0016

164. Maggi A. Liganded and Unliganded Activation of Estrogen Receptor and Hormone Replacement Therapies. Biochim Biophys Acta (BBA)-Mol Basis Dis (2011) 1812:1054-60. doi: 10.1016/j.bbadis.2011.05.001

165. Taylor HS. Designing the Ideal Selective Estrogen Receptor Modulator-an Achievable Goal? Menopause (New York NY) (2009) 16:609. doi: 10.1097/ gme.0b013e3181906fa3

166. Maximov Y, Lee M, Craig Jordan V. The Discovery and Development of Selective Estrogen Receptor Modulators (SERMs) for Clinical Practice. Curr Clin Pharmacol (2013) 8:135-55. doi: 10.2174/1574884711308020006

Conflict of Interest: The authors declare that the research was conducted in the absence of any commercial or financial relationships that could be construed as a potential conflict of interest.

Publisher's Note: All claims expressed in this article are solely those of the authors and do not necessarily represent those of their affiliated organizations, or those of the publisher, the editors and the reviewers. Any product that may be evaluated in this article, or claim that may be made by its manufacturer, is not guaranteed or endorsed by the publisher.

Copyright (c) $2022 \mathrm{Xu}$, Huang, Yu, Li, Fu and Deng. This is an open-access article distributed under the terms of the Creative Commons Attribution License (CC BY). The use, distribution or reproduction in other forums is permitted, provided the original author(s) and the copyright owner(s) are credited and that the original publication in this journal is cited, in accordance with accepted academic practice. No use, distribution or reproduction is permitted which does not co 7 mply with these terms. 